\title{
Review \\ Genetic and Environmental Factors Influence the Pleomorphy of LRRK2 Parkinsonism
}

\author{
Vinita G. Chittoor-Vinod (D), R. Jeremy Nichols * and Birgitt Schüle *(D) \\ Department Pathology, Stanford University School of Medicine, Stanford, CA 94305, USA; chittoor@stanford.edu \\ * Correspondence: rjnichols@stanford.edu (R.J.N.); bschuele@stanford.edu (B.S.)
}

check for

updates

Citation: Chittoor-Vinod, V.G.; Nichols, R.J.; Schüle, B. Genetic and Environmental Factors Influence the Pleomorphy of LRRK2 Parkinsonism. Int. J. Mol. Sci. 2021, 22, 1045. https://doi.org/10.3390/ijms22031045

Academic Editor: Ornit Chiba-Falek

Received: 22 December 2020

Accepted: 17 January 2021

Published: 21 January 2021

Publisher's Note: MDPI stays neutral with regard to jurisdictional claims in published maps and institutional affiliations.

Copyright: (c) 2021 by the authors. Licensee MDPI, Basel, Switzerland. This article is an open access article distributed under the terms and conditions of the Creative Commons Attribution (CC BY) license (https:// creativecommons.org/licenses/by/ $4.0 /)$.

\begin{abstract}
Missense mutations in the LRRK2 gene were first identified as a pathogenic cause of Parkinson's disease (PD) in 2004. Soon thereafter, a founder mutation in LRRK2, p.G2019S (rs34637584), was described, and it is now estimated that there are approximately 100,000 people worldwide carrying this risk variant. While the clinical presentation of LRRK2 parkinsonism has been largely indistinguishable from sporadic PD, disease penetrance and age at onset can be quite variable. In addition, its neuropathological features span a wide range from nigrostriatal loss with Lewy body pathology, lack thereof, or atypical neuropathology, including a large proportion of cases with concomitant Alzheimer's pathology, hailing LRRK2 parkinsonism as the "Rosetta stone" of parkinsonian disorders, which provides clues to an understanding of the different neuropathological trajectories. These differences may result from interactions between the LRRK2 mutant protein and other proteins or environmental factors that modify LRRK2 function and, thereby, influence pathobiology. This review explores how potential genetic and biochemical modifiers of LRRK2 function may contribute to the onset and clinical presentation of LRRK2 parkinsonism. We review which genetic modifiers of $L R R K 2$ influence clinical symptoms, age at onset, and penetrance, what $L R R K 2$ mutations are associated with pleomorphic $L R R K 2$ neuropathology, and which environmental modifiers can augment $L R R K 2$ mutant pathophysiology. Understanding how LRRK2 function is influenced and modulated by other interactors and environmental factors—either increasing toxicity or providing resilience-will inform targeted therapeutic development in the years to come. This will allow the development of disease-modifying therapies for PD- and LRRK2-related neurodegeneration.
\end{abstract}

Keywords: Parkinson's disease; parkinsonism; LRRK2; neuropathology; modifier; genetics; GWAS; environmental risk factors; polygenic risk score

\section{Introduction}

In 2004, missense mutations in the LRRK2 (leucine-rich repeat kinase 2) gene were identified in the Japanese Sagamihara kindred as a pathogenic cause of Parkinson's disease (PD), as well as in families of other ethnic backgrounds across the world [1,2]. While the clinical presentation of motor symptoms of $L R R K 2$ parkinsonism has been largely indistinguishable from sporadic PD, there is a striking difference in the age at onset (AAO), disease penetrance, and neuropathological features, ranging from nigrostriatal loss with inconsistent occurrences of Lewy body (LB) and Alzheimer's pathology, lack thereof, or atypical neuropathology. These differences in disease presentation could result from interactions between the LRRK2 mutant protein and certain protein or environmental modifiers. Its clinical and neuropathological heterogeneity implies that other factors could influence pathobiology, which might require or yield distinct therapeutic approaches. In this review, we describe (1) the clinical and neuropathological similarities and differences of $L R R K 2$ parkinsonism with sporadic or idiopathic PD (iPD); (2) what genetic modifiers of $L R R K 2$, including Mendelian PD genes, GWAS risk factors, and polygenic risk scores, modify disease risk; (3) what $L R R K 2$ mutations are associated with pleomorphic $L R R K 2$ neuropathology; (4) what environmental modifiers affect $L R R K 2$ parkinsonism. 


\subsection{Clinical Presentation and Incidence of PD}

$\mathrm{PD}$ is a common neurodegenerative movement disorder affecting dopaminergic neurons in the substantia nigra and other projection neurons in both the central and peripheral nervous systems [3,4]. The overall prevalence of PD in people over 45 years of age was estimated at 572 per 100,000 in 2010 in the US [5]. Approximately 930,000 people in the US were affected with PD in 2020, and, based on US Census Bureau population projections, it will rise to $1,238,000$ by 2030 [5]. Clinically, distinct motor and nonmotor symptoms lead to a diagnosis of $\mathrm{PD}[6,7]$, although the rate of misdiagnosis is quite high, with only $58 \%$ accuracy for the initial diagnosis of PD [8]. Motor symptoms are comprised of bradykinesia, resting tremor, rigidity, and postural instability with an asymmetrical onset of symptoms. Nonmotor symptoms include loss of sense of smell, sleep/REM disorder, dysphagia, autonomic dysfunction such as constipation, urinary problems, changes in heart rate variability, and psychiatric problems with anxiety and depression as well as cognitive decline [9-11]. More men than women are diagnosed with PD. While the incidence ratio is $<1.2$ in males and females under the age of 50, it increases to 1.6 over 80 years of age [12]. About $10-15 \%$ of all PD patients and about $25 \%$ of early-onset PD cases in a clinical setting report a family history of PD [13].

\subsection{LRRK2 Variants, Haplotypes, and Penetrance PD}

The LRRK2 p.G2019S (NM_198578.4 (LRRK2): c.6055G > A) variant is estimated to occur in approximately $1 \%$ of patients with sporadic PD and 3-6\% of patients with familial PD in the United States; it shows the highest penetrance of all reported LRRK2 risk variants (Table 1). The LRRK2 p.G2019S mutation is common in the European, Middle Eastern, and North African populations. There is a wide range for AAO of mutation carriers, ranging from the third to the seventh decade of life [14]. Carrier frequency in Ashkenazi Jewish PD patients is $15-20 \%$; for North African Berbers, it is up to $40 \%[15,16]$. Several groups have studied the genomic background of the LRRK2 p.G2019S haplotype, and data suggest that there have been at least three different founding events that gave rise to the LRRK2 p.G2019S mutation between 1500-4500 years ago [17-19].

Penetrance for LRRK2 p.G2019S has been reported to be variable, ranging from $24-100 \%$, and penetrance seems to increase with age. This wide range can be attributed to differences in study cohorts, ethnic groups, the presence of genetic or environmental modifiers, and recruitment or analysis methods [20,21]. In the Michael J. Fox Foundation (MJFF) Ashkenazi consortium, studying 2270 relatives of 474 cases of Ashkenazi Jewish descent, a penetrance of $26 \%$ was found [20]. Comparison of penetrance for non-Ashkenazi Jewish carriers with Ashkenazi Jewish carriers did not differ significantly, with $25-42.5 \%$ at age 80 [22].

Besides the LRRK2 p.G2019S mutation, many missense and some loss-of-function mutations have been described. However, proof of pathogenicity is pending on many of these mutations, owing to their rarity and scarce functional studies [19,23,24]. Importantly, loss of function mutations, such as stop-codon and frameshift mutations, were shown to not contribute to PD risk [24,25]. In a comprehensive meta-analysis, including 94 articles covering 49,299 cases and 47,319 controls, a number of common variants were assessed for the risk of developing PD. The LRRK2 p.A419V (odds ratio (OR) 2.45), p.R1441C/G/H (OR 12.75), p.R1628P (OR 2.13), p.G2019S (OR 13.16), and p.G2385R (OR 2.27) mutations were associated with increased PD risk, whereas p.R1398H (OR 0.81) was associated with a decreased risk for PD [26] (Table 1).

\subsection{LRRK2 Domain Structure and the Impact of Inherited Mutations}

LRRK2 is a large, multidomain protein of 2527 amino acids (aa), with both GTPase and kinase enzymatic domains (Figure 1). The amino terminus (1-1287aa) is not essential for intrinsic kinase or GTPase activity [27] but participates in the regulation of LRRK2. The amino terminus contains armadillo and ankyrin repeats, the namesake leucine-rich repeat domain, and a cluster of crucial phosphorylation residues (Ser910 and Ser935 [28,29]). 
Full kinase catalytic activity requires the remainder of the protein (1326-2527aa [27,30]). This minimal catalytic fragment includes an active GTPase domain, termed Roc (Ras of complex proteins), which is juxtaposed to the COR (C-terminal of ROC) domain, classifying LRRK2 as a ROCO family protein [31,32]. The GTPase domain of LRRK2 can be purified as an active monomer/dimer that binds and hydrolyzes GTP [33], implicating that the RocCOR domain likely participates in the dimerization of LRRK2 [34-36]. The adjacent kinase domain bears similarity to mixed-lineage kinases, which are typically involved in kinase signaling cascades. The carboxy terminus contains a WD40 domain and is essential for kinase activity, where deletion of the last seven amino acids inactivate LRRK2 via disruption of the WD40 fold $[27,37,38]$.

High-risk variants in the LRRK2 gene encode substitutions in the catalytic core of the LRRK2 GTPase and kinase domains (p.N1437H, p.R1441C/G/H, p.Y1699C, p.G2019S, p.I2020T; Table 1 and Figure 1) [30,39-42]. The LRRK2 p.G2019S mutation is located in subdomain VII of the kinase domain "Asp-Phe-Gly (DFG)" motif [43-45] and displays a 2- to 3-fold increase in kinase activity in vitro and in vivo [28,42,46,47]. Structural studies suggest that the serine substitution at position 2019 for the glycine in the DFG motif stabilizes an active state of LRRK2, resulting in the increased kinase activity [47-49]. The LRRK2 p.I2020T mutation displays decreased activity in some assays and increased activity in others $[27,30,50,51]$, possibly due to substrate-dependent readouts of kinase activity [52]. Mutations in the RocCor domain, p.N1437H, p.R1441C/G/H, and p.Y1699C, are thought to disrupt GTP hydrolysis, leaving LRRK2 in a GTP-bound, active kinase state, mediating increased kinase activity [33]. Noncatalytic domains of LRRK2 can also harbor PD, causing mutations. The LRRK2 p.G2385R mutation decreases kinase activity of LRRK2 in vitro $[27,37,38,53]$ but displays reduced Hsp90 interaction and 14-3-3 binding, with increased activity against Rab substrates in cells [30]. Conversely, LRRK2 p.G2385R de-stabilizes LRRK2 dimers isolated from cultured cells and shows significantly elevated kinase activity [54]. Overall, there is a correlation between PD-causing LRRK2 mutations and an elevation in LRRK2 kinase activity or higher net signaling of LRRK2, which could mediate a differential response to upstream modifiers and provide a plausible explanation for the variability in their associated PD pathophysiology.

\subsection{LRRK2 Parkinsonism: Similarities and Differences to iPD}

LRRK2 parkinsonism has been hailed as the "Rosetta stone" of parkinsonian disorders as brains from $L R R K 2$ cases demonstrate all major pathologies associated with parkinsonism, including a large proportion with concomitant Alzheimer's pathology [55-59]. LRRK2 could hold the key to unlocking answers as to why different neuropathological changes can arise from underlying genetic changes in this gene. Currently, the pathways and potential disease modifier genes that explain this striking pleomorphic presentation of LRRK2 parkinsonism and variable clinical penetrance/AAO are unknown, although many cellular phenotypes and molecular pathways, including endolysosomal stress [60-62], neuroinflammation [63-65], mitochondrial dysfunction and damage [66,67], and alterations of exosomes $[68,69]$ have been described due to altered LRRK2 signaling. Mendelian PD genes, GWAS risk factors, and polygenic risk scores have been nominated as influencing factors for $L R R K 2$, but studies that validate these putative modifiers are lacking. 
Table 1. $L R R K 2$ variant overview.

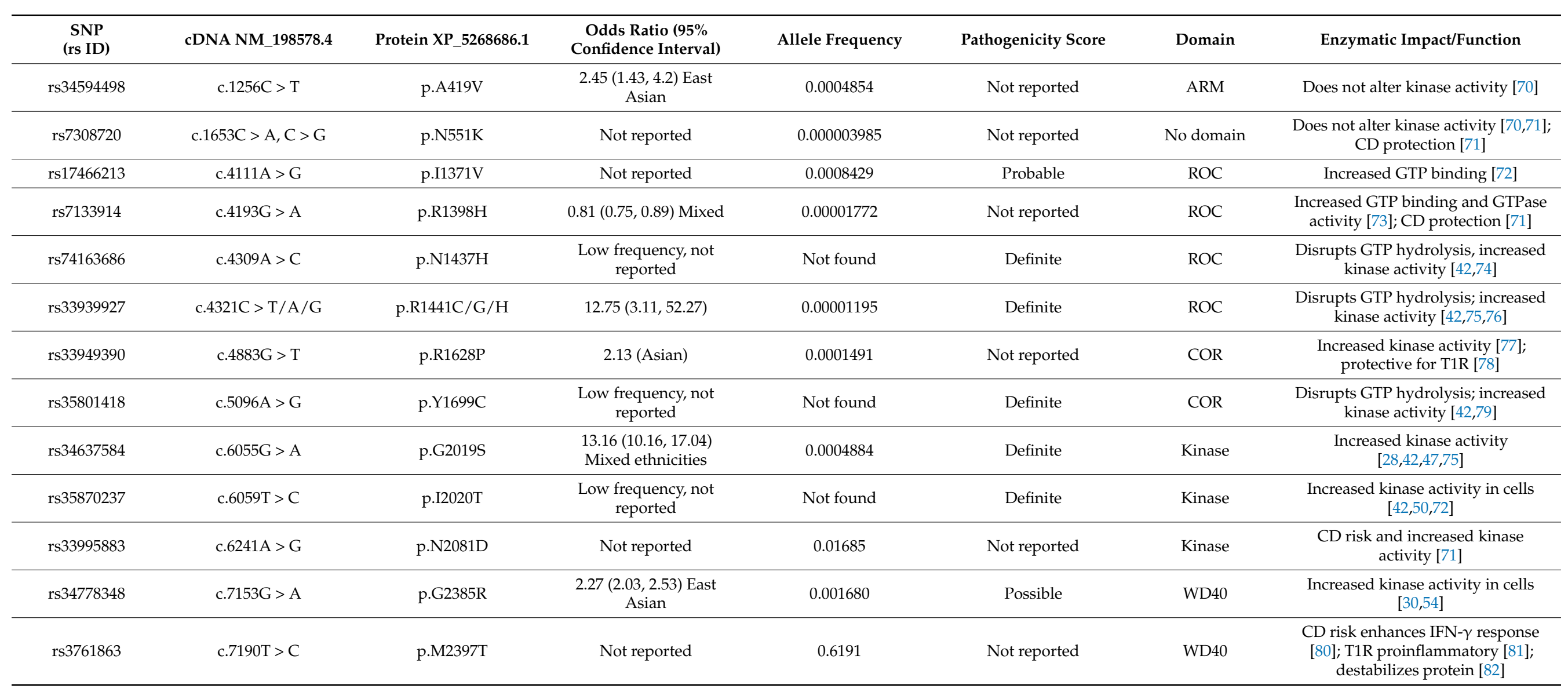

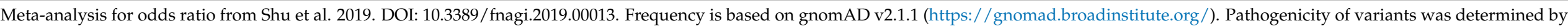
MDSGene (https:/ / www.mdsgene.org/). 


\subsubsection{Motor and Nonmotor Features in LRRK2-PD}

LRRK2 parkinsonism can present with the same cardinal motor and nonmotor symptoms as sporadic PD [83] (we will refer to such patients and cohorts as LRRK2-PD), although the disease course and progression appear to be slightly more benign, as described in a recent meta-analysis of 66 clinical research studies evaluating the clinical phenotype of PD cases with p.G2019S, p.G2385R, p.R1628P, and p.R1441G LRRK2 mutations [84]. Overall, LRRK2-PD presents with higher rates of early-onset PD, a higher female ratio, and family history, which can be explained by the strong genetic contribution [85]. PD patients with LRRK2 p.G2019S have lower depression rates and higher daily activity scores as well as better olfactory function compared to sporadic PD [84]. LRRK2 p.G2019S and p.G2385R have a good response to a higher daily dose of L-dopa, albeit with more motor complications than PD non-LRRK2 carriers. LRRK2 p.G2385R-affected carriers present with milder motor scores and better cognitive function. No distinct clinical features for LRRK2 p.R1628P or p.R1441G have been detected [84]. In a prospective study of 144 LRRK2 p.G2019S-PD and 401 non- $L R R K 2-\mathrm{PD}$, a slower decline in motor function was described among those with LRRK2 p.G2019S-associated PD [86]. Interestingly, relatives of LRRK2-PD ( $n=142$, independent of mutation carrier status) present with a worse motor score and anxiety compared to 172 controls, implying that other environmental or non-LRRK2 genetic modifiers might influence the penetrance of LRRK2 p.G2019S-PD [87]. Nonmotor features and early predictors of PD also include reduced heart-rate variability (HRV) and cardiac sympathetic neurodegeneration [88,89]. In a study using classic HRV parameters, there was no difference between 20 LRRK2-PD and 32 healthy controls [90]. However, a follow-up study of an overlapping cohort analyzed novel HRV parameters and showed that there was more vagal involvement in 14 LRRK2-PD compared to 27 healthy controls and even in a subset of $L R R K 2$ non-manifesting carriers (a total group of 25 non-manifesting LRRK2 carriers), suggesting a preclinical endophenotype of impairment of cardiac innervation [91].

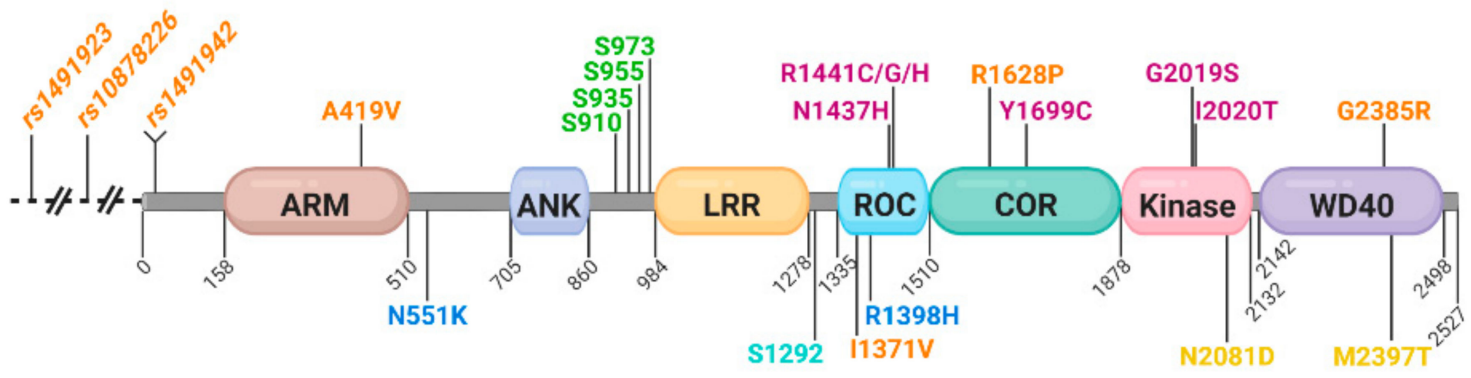

Figure 1. Domain architecture, genetic risk variants, and regulatory phosphorylation sites of LRRK2 (leucine-rich repeat kinase 2). LRRK2 is a large kinase of 2527 amino acids with multiple identifiable functional domains. Variants classified as pathogenic according to MDSGene are in magenta, while risk factor variants pending conclusive classification are in orange; putative protective mutations are in blue; variants associated with inflammatory bowel disease (IBD) are in yellow. Regulatory phosphorylation sites are in green, and LRRK2 autophosphorylation site Ser1292 is in teal. ARM-armadillo domain; ANK—ankyrin domain; LRR—leucine-rich repeat domain; Roc-GTPase domain; COR—carboxy terminal of Roc domain.

1.4.2. Cortico-Striato-Nigral Connectivity Alterations in Asymptomatic LRRK2 p.G2019S Mutation Carriers

As disease penetrance for $L R R K 2$ p.G2019S is between $24-100 \%$ [20,21], there is interest in understanding the effect of this high-risk variant in asymptomatic carriers in order to develop disease-specific biomarkers and endophenotypes that could support early disease detection. Functional imaging studies of asymptomatic LRRK2 p.G2019S carriers compared to healthy controls have shown changes in executive function and reward-based neural processing, suggesting alterations in neuronal networks and connectivity. Asymptomatic LRRK2 p.G2019S mutation carriers $(n=27)$ show a reorganization of corticostriatal circuits 
similar to iPD, which is more pronounced with the increased age of LRRK2 p.G2019S carriers compared to asymptomatic non-LRRK2 carriers $(n=32)$ [92]. In resting-state magnetic resonance imaging (MRI), there was reduced integrity of nonmotor networks detected in asymptomatic LRRK2 p.G2019S $(n=44)$ compared to asymptomatic non-LRRK2 carriers $(n=41)$ before changes in the connectivity of the motor network were present, which illustrates that nonmotor cerebral changes delineate LRRK2 p.G2019S carriers as "at risk" for developing PD [93]. Another study using resting-state MRI also found that altered brain connectivity precedes the onset of PD motor features. Asymptomatic LRRK2 p.G2019S carriers $(n=18)$ showed functional connectivity changes in striatocortical and nigrocortical circuits compared to non-LRRK2 first-degree relatives $(n=18)$ [94]. The connectivity alterations in asymptomatic $L R R K 2$ carriers may represent neural compensatory mechanisms. In the Stroop color-word interference test, LRRK2 p.G2019S carriers $(n=19)$ had similar behavioral performance compared to 21 first-degree relative asymptomatic non-LRRK2 carriers but had increased activity in brain regions comprising the ventral attention system [95]. In a study testing an event-related functional MRI gambling task to assess the reward network, abnormal neural activity in the reward and motor networks were detected in asymptomatic LRRK2 p.G2019S carriers $(n=36)$ compared to controls $(n=32)$, indicating the involvement of the ventral striatum [96]. Another example of potential compensatory functional changes is that manifesting $(n=14)$ and non-manifesting $(n=16)$ LRRK2 carriers exhibit increased cortical cholinergic activity compared to iPD $(n=8)$ and controls $(n=11)$ [97]. Overall, these findings show that circuit structure and function in LRRK2 p.G2019S carriers are already altered before symptom onset and, presumably, already reorganized during neuronal development and brain maturation, suggesting that LRRK2 p.G2019S carriers require compensatory mechanisms for normal cognitive function, which makes them potentially more susceptible to PD. While the studies include a small number of participants and are potentially underpowered, these are critical studies that further investigation. This invokes an interesting question of whether these compensatory functional effects are related to LRRK2 modifiers and could lead to parallel pathways that also affect PD pathophysiology.

\subsection{Pleomorphic LRRK2 Neuropathology}

The neuropathological changes that underlie the clinical PD spectrum are subtyped as PD, dementia with Lewy bodies (DLB), and Parkinson's disease dementia (PDD); they are characterized by the formation of intracellular protein inclusions and immunoreactive for alpha-synuclein ( $\alpha$-syn) and its pathological forms such as phosphorylated S129 $\alpha$-syn $[39,98]$. The neurons most vulnerable for LB pathology are projection neurons with disproportionately long axons and poor myelination, exemplified by dopaminergic neurons projecting from the substantia nigra to the striatum [3,99]. In addition, it is becoming more evident that there is overlapping pathology in older adults, with up to $20 \%$ of quadruple neuropathology (tau neurofibrillary tangles, amyloid- $\beta(\mathrm{A} \beta$ ), $\alpha$-syn, and transactive response DNA-binding protein 43 (TDP-43)) in cases with dementia associated with a progressive course of disease [100].

After early reports of $L R R K 2$ neuropathology in human postmortem cases, it became apparent that $L R R K 2$ parkinsonism presents with heterogeneous neuropathology, including pure nigral-striatal degeneration or typical LB pathology, but also cases with multiple system atrophy (MSA) or progressive supranuclear palsy (PSP) staining with variable concomitant Alzheimer's pathology [55,101,102]. This neuropathological heterogeneity cannot be explained by allelic variation in functional domains of LRRK2 since variability has been reported for pathology associated with all variants (Table 2, Figure 2). In iPD, approximately $5 \%$ of cases with clinically diagnosed PD present with postmortem neuropathological findings of pure nigrostriatal or substantia nigra degeneration (SND), while $77 \%$ are an LB disease, including brainstem predominant, transitional, and diffuse LB disease. MSA is found in $5 \%$ of clinical PD cases; PSP, especially the parkinsonism form (PSP-P), is found in $11 \%$ of probable PD according to Hoehn and Yahr staging without 
dementia [98]. Notably, these numbers are quite different in LRRK2 parkinsonism cases (Figure 2). In $L R R K 2$ parkinsonism, the number of cases with pure substantia nigra degeneration is $33 \%$ (24 out of 73), while cases with typical LB pathology only comprise $38 \%$ (28 out of 73; Table 2). Mutations in the three catalytic core domains, Roc, COR, and kinase, can present with nigrostriatal degeneration, which includes p.R1441C/G/H, p.Y1699C, p.G2019S, and p.I2020T [55-57,103].

While rare, three pathogenic $L R R K 2$ cases with pathologically proven MSA have been described, which represent about $4 \%$ (3 out of 73 LRRK2 cases) of all reported LRRK2 parkinsonism cases. All cases harbored different mutations: one is located in the Roc domain (LRRK2 p.I1371V [58]), and two are in the kinase domain (LRRK2 p.I2020T [104] and LRRK2 p.G2019S [105]). Histopathologically, in MSA, $\alpha$-syn is found as aggregates, called glia cytoplasmic inclusions (GCIs), in oligodendroglia rather than neurons and are distinct from LBs. LRRK2 has been found in oligodendroglia in MSA and is colocalized with GCIs as well as degrading myelin sheaths, which are one of the earliest cellular abnormalities that have been described in MSA [106]. One LRRK2 p.G2019S case, which also involved the MAPT variant p.Q124E, was described with occasional TDP-43 inclusions, nigral degeneration without Lewy bodies, and Alzheimer-type tau pathology [107].
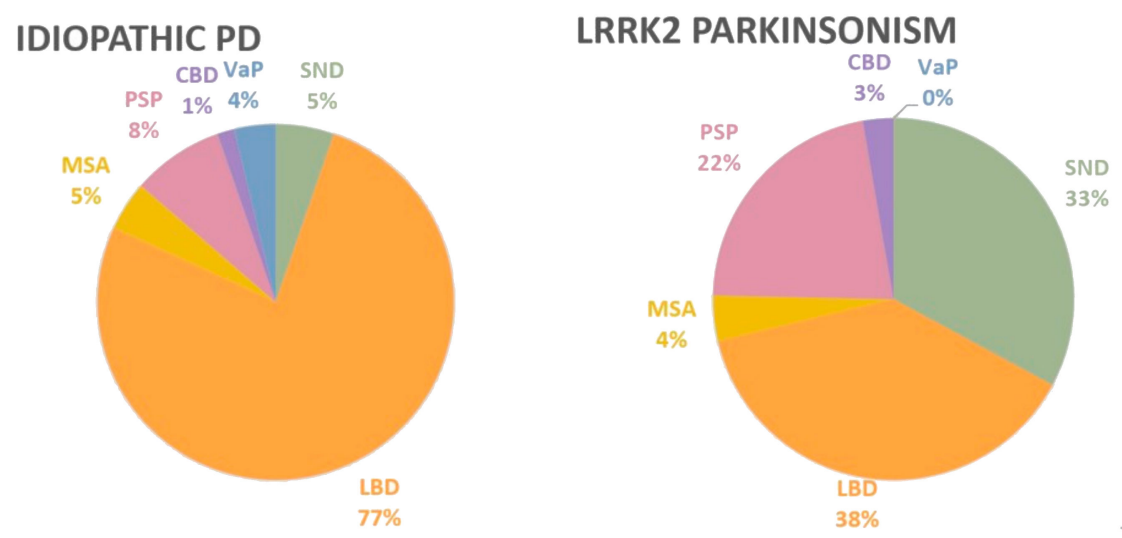

Figure 2. Frequency of neuropathologic disorders with a clinical diagnosis of idiopathic Parkinson's disease (PD) and LRRK2 parkinsonism. The pie charts show the frequency of pathologic disorders that present with clinical parkinsonism without dementia $(n=132)$, adapted from Dickson et al. (2018) [98], and LRRK2-PD from cases and case series described in the literature ( $n=74$; Table 1$)$. Abbreviations: Lewy body disorder (LBD), multiple system atrophy (MSA), progressive supranuclear palsy (PSP), corticobasal degeneration (CBD), vascular parkinsonism (VaP), and substantia nigra degeneration (SND). For details on neuropathological assessments, see Table 2.

Approximately $22 \%$ of all LRRK2 cases (16 out of 73 ) have been described with neuropathological changes of hyperphosphorylated tau resembling PSP (Figure 2, Table 2). PSP is a 4R tauopathy with tau aggregates in neurons and glia in specific neuroanatomical regions such as basal ganglia, diencephalon, brainstem, and cerebellum. One case with LRRK2 p.R1441C, four with LRRK2 p.I2020T, and five with LRRK2 p.G2019S have been described in the literature with PSP [1,108-111]. Additionally, two cases with the risk variant $L R R K 2$ p.R1628P and one variant of unknown significance (LRRK2 p.A1413T) have been reported with neuropathological changes compatible with PSP [112]. Two cases with LRRK2 variants (p.R1707K and p.R2618P) have also shown neuropathology of corticobasal degeneration (CBD) [112]. 
Table 2. LRRK2 cases with a neuropathological assessment.

\begin{tabular}{|c|c|c|c|c|c|c|c|c|c|c|c|c|}
\hline LRRK2 Mutation & Clinical Presentation & \# of Cases & SND & LBD & MSA & PSP & CBD & TDP-43 & Low AD & Interim AD & High AD & References \\
\hline \multirow[t]{2}{*}{ c.4111A > G (p.I1371V) } & $\mathrm{PD}$ & 1 & - & 1 & - & - & - & - & - & - & - & {$[55,113]$} \\
\hline & MSA & 1 & - & - & 1 & - & - & - & - & - & - & {$[58]$} \\
\hline c.4309C > A (p.N1437H) & PD & 1 & - & 1 & - & - & - & - & 1 & - & - & {$[55,114]$} \\
\hline \multirow[t]{3}{*}{$\begin{array}{l}\text { c. } 4321 \mathrm{C}>\mathrm{T} / \mathrm{G} \\
\text { (p.R1441C/G) }\end{array}$} & PD & 6 & 3 & 2 & - & 1 & - & - & - & - & - & [115] \\
\hline & $\mathrm{PD}$ & 4 & 1 & 2 & - & 1 & - & - & - & - & - & [1,116] (Family D, R1441C) \\
\hline & PD & 6 & 3 & 2 & - & 1 & - & - & - & - & - & {$[1,55,115]$} \\
\hline c.4322 G > A (p.R1441H) & $\mathrm{PD}$ & 3 & 3 & - & - & - & - & - & - & - & - & {$[57]$} \\
\hline c.5096A > G (p.Y1699C) & $\mathrm{PD}$ & 3 & 2 & 1 & - & - & - & - & - & - & 1 & $\begin{array}{l}\text { [55,117] (Lincolnshire, } \\
\text { III.13), [1,118] (Fam A, } \\
\text { III.27, III.29) }\end{array}$ \\
\hline \multirow[t]{7}{*}{ c.6055G > A (p.G2019S) } & 2 PD, 3 PDD & 5 & 1 & 2 & - & 2 & - & - & 1 & 3 & 1 & {$[24]$} \\
\hline & 7 PD, 2 PDD & 9 & 4 & 5 & - & - & - & - & - & - & 3 & $[56,119]$ ( 3 cases $)$ \\
\hline & MSA & 1 & - & - & 1 & - & - & - & - & - & - & {$[105]$} \\
\hline & PSP & - & - & - & - & 2 & - & - & - & - & - & {$[108]$} \\
\hline & $\mathrm{PD}$ & 1 & 1 & - & - & - & - & - & 1 & - & - & [103] \\
\hline & PSP & 1 & - & - & - & 1 & - & - & 1 & - & - & [112] \\
\hline & $\mathrm{PD}$ & 1 & - & - & - & - & - & 1 & - & - & 1 & $\begin{array}{l}\text { [107], patient also carries } \\
\text { MAPT c.370C > G, } \\
\text { (p.Q124E) variant }\end{array}$ \\
\hline c.6059T > C (p.I2020T) & PD/MSA/PSP & 9 & 5 & 1 & 1 & 4 & - & - & - & - & - & $\begin{array}{c}\text { Sagamihara } \\
{[55,104,109,122,123]} \\
\text { (4 cases with tau pathology) }\end{array}$ \\
\hline c.3494T > C, p.L1165P & PDD, Pat. E & 1 & - & 1 & - & - & - & - & - & - & 1 & {$[56,124]$} \\
\hline c.2378 G > T, p.R793M & PD, Pat. D & 1 & - & 1 & - & - & - & - & - & 1 & - & {$[56,124]$} \\
\hline c.5120G > A, p.R1707K & $\mathrm{CBD}$ & 1 & - & - & - & - & 1 & - & - & - & 1 & [112] \\
\hline c. $4883 \mathrm{G}>$ T, p.R1628P & $\mathrm{PSP} / \mathrm{CBD}$ & 3 & - & - & - & 2 & 1 & - & - & - & - & [112] \\
\hline c.4237G > A, p.A1413T & PSP & 1 & - & - & - & 1 & - & - & - & - & - & [112] \\
\hline Total cases & & 74 & 24 & 28 & 3 & 16 & 2 & 1 & 4 & 4 & 9 & \\
\hline
\end{tabular}

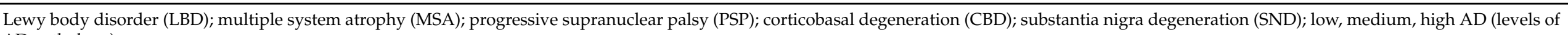
AD pathology). 
Coexistent Alzheimer's pathology is well known as part of the natural history of PD. Especially in PD cases with cognitive decline, $94 \%$ of them have been described with concomitant neuropathological changes of $\mathrm{AD}$, whereas cases without dementia rarely present with AD pathology [125]. In LRRK2 parkinsonism, a large proportion of cases with clinically diagnosed PD or PDD also have significant concomitant Alzheimer's disease pathology with or without LBs (12 out of 15 cases) [56,110].

In conclusion, it appears that $L R R K 2$ parkinsonism cases with pure nigrostriatal degeneration are six times more frequent compared to iPD (33\% vs. $5 \%$ ), whereas typical LB pathology is reported at half the frequency as iPD (38\% vs. $77 \%)$. MSA seems to occur at similar frequencies between LRRK2 parkinsonism and sporadic PD, but LRRK2 cases with PSP are 2.5 times higher than iPD ( $22 \%$ vs. $8 \%$; Figure 2$)$. These striking differences in neuropathological characteristics indicate that there are likely different disease modifiers of mutant LRRK2 or environmental modifiers that affect neurodegenerative trajectories of $\alpha$ syn and tau pathology in LRRK2 parkinsonism in vulnerable cell populations. A deficiency in the lysosomal-autophagy catabolic system is an attractive explanation for the causes of neurodegenerative diseases due to the overlap in phenotypes of several neurodegenerative model systems and the overall observation of a decrease in lysosomal functionality with age. However, a lysosomal centric explanation of cell death is insufficient to explain the increase in $4 \mathrm{R}$ tau for PSP and the increase in SND pathology in LRRK2 parkinsonism. To try to understand how LRRK2 mutations contribute to the shift in the proportion of $\alpha$-syn and tau neuropathologies, alternative explanations need to be found. For example, for the contribution to LRRK2-mediated PSP, a transgenic LRRK2 mouse model showed an increase in $4 \mathrm{R}$ tau [126], which could indicate an effect of $L R R K 2$ on tau splicing. Lack of protein $\alpha$-syn and tau aggregation in LRRK2 parkinsonism leaves an open question, and other factors such as gene regulation, immune response, or mitochondrial dysfunction could be at play.

\section{Environmental Modifiers of LRRK2 Parkinsonism}

\subsection{Environmental and Lifestyle Factors Influence Penetrance and Age at Onset of LRRK2 Parkinsonism}

Environmental and lifestyle factors, head injury, and exposure to industrial toxicants, including pesticides, solvents, or metals, among other pollutants, have been found to increase the risk for PD. Effects of these environmental exposures have been in animal models [127-129]. Some environmental factors have been associated with a decreased prevalence of PD, including smoking history, caffeine and tea consumption, use of nonsteroidal anti-inflammatory drugs (NSAIDs), and physical activity [130]. Lifestyle changes such as dietary alterations have been considered for their protective effects on neurodegenerative diseases, including AD and PD [131]. Such dietary changes can even be investigated in fly models with LRRK2 p.G2019S, and they have shown a protective effect of dietary amino acids on dopamine neuron survival and motor function [132].

It is intriguing to hypothesize that environmental or lifestyle factors also influence the risk for $L R R K 2-\mathrm{PD}$, specifically disease penetrance and AAO. Interestingly, a study showed that $L R R K 2$ carriers with a history of cigarette smoking had a later AAO compared to nonsmokers, suggesting that smoking could modify AAO in LRRK2-PD [133]. Furthermore, regular use of NSAIDs (ibuprofen and aspirin) is associated with reduced penetrance in LRRK2-associated PD. This study included 259 LRRK2-PD and 318 LRRK2-asymptomatic participants; regular NSAID use resulted in reduced risk for PD in the overall cohort (OR: 0.34), including LRRK2 p.G2019S, p.R1441C/G, p.I2020T, p.G2385R, and p.R1628P variants [134]. With consortium efforts, these emerging studies in LRRK2 cohorts will hopefully be validated and expanded for other modifying environmental factors in the future.

\subsection{Increased Susceptibility to Synthetic Toxicants in LRRK2 Animal Models}

Environmental toxicants associated with the manifestation of PD mainly comprise inhibitors of mitochondrial complexes and/or inducers of cellular reactive oxygen species 
(ROS) [129]. These toxicants have been intensively investigated in animal models of PD. LRRK2 mutant protein contributes to multiple pathways and mechanisms, including neuroinflammation [64], endolysosomal and oxidative stress [61,135,136], and mitochondrial dysfunction and clearance $[67,137]$. Variable penetrance and AAO also suggest multiple hits for disease development [138,139], including predisposing germline gene mutations, acquired somatic gene variants [140], the environmental factors described in Section 2.1, and aging [141].

1-Methyl-4-phenyl-1,2,3,6-tetrahydropyridine (MPTP), a contaminant of the synthetic opiate meperidine, was identified as a neurotoxic compound that leads to an acute form of parkinsonism [142,143]. Neurodegeneration associated with LRRK2 p.G2019S expression is augmented in mice after MPTP administration; however, mice expressing human WT $L R R K 2$ exhibit a similar response to MPTP as non-transgenic animals [144,145]. Subtoxic exposure to MPTP increases motor impairment, dopaminergic cell loss, and astrocyte activation, which can be partially reversed by pharmacological LRRK2 kinase inhibition [145]. On the other hand, mice that lack the LRRK2 kinase domain do not show any difference in MPTP sensitivity when compared to WT animals [146]. MPTP administration increases LRRK2 transcript levels together with other PD-related proteins such as Parkin, PINK1, MUL1, and USP30 in both non-transgenic rodents and rhesus monkeys [147,148] and, thereby, could further contribute to the neurotoxicity in LRRK2 mutant models.

Paraquat (PQ; 1,1'-dimethyl-4-4'-bipyridinium) is an herbicide that bears a close structural resemblance to $\mathrm{MPP}+$ that interferes with electron transport in the mitochondria to promote the formation of ROS. Studies show that PQ exposure also increases motor impairment in LRRK2-overexpressing animals. Both WT and mutant LRRK2 variants evoke a similar response to PQ in rodents $[149,150]$. However, knock-down of endogenous LRRK2 leads to PQ resistance in mice and flies [149,151,152]).

Rotenone is a broad-spectrum organic pesticide that occurs naturally in several plants. Rotenone is an inhibitor of mitochondrial complex I and has been widely used for neurotoxic modeling in PD $[153,154]$. Mice with LRRK2 p.R1441G knock-in show clear motor deficits upon rotenone exposure compared to WT LRRK2 mice treated with rotenone [155]. Studies from Drosophila also advocate that rotenone treatment exacerbates dopamine neuron loss and motor impairment in LRRK2 transgenic animals [156,157], although different $L R R K 2$ variants may display variable susceptibilities towards this neurotoxin [157]. Furthermore, LRRK2 kinase inhibitors render resistance to rotenone toxicity, as seen in rats and human Wharton's-jelly-derived mesenchymal stromal cells (hWj-MSCs) [158,159]. Reinhardt et al. showed that sensitivity to rotenone and 6-OHDA (6-hydroxy-dopamine) is higher in iPSC-derived midbrain dopamine neurons when a p.G2019S mutation is introduced into the LRRK2 locus [160]. Together, there is compelling evidence that exposure to environmental neurotoxins can act as a second hit to LRRK2 pathology, thus exaggerating the associated pathology.

Similar to other dominant genetic PD transgenic models and models of gene-environment interactions on nigrostriatal toxicity [161-163], LRRK2 mutations seem to sensitize and augment the underlying toxicant-induced phenotype. Likewise, expression of SNCA p.A53T also increases susceptibility to toxicants [164,165]. Conversely, overexpression of recessive PD gene products (modeling reversal of inherited mutation) is protective against toxicants [166].

\section{LRRK2 Risk and Protective Variants in Neurodegeneration and Genetic Modifiers of AAO and Penetrance in LRRK2 Parkinsonism}

\subsection{LRRK2 Modifier Risk Variants}

Risk variants for PD derived from GWAS or candidate gene studies have been tested in association studies in LRRK2 cohorts. Such PD risk variants are located in SNCA, dynamin3 (DNM3), cyclin-G-Associated Kinase $(G A K)$, brain-derived neurotrophic factor $(B D N F)$, microtubule-associated protein tau $(M A P T)$, bone marrow stromal cell antigen 1 (BST1), Ras-related protein Rab-29 (Rab29/PARK16), and vesicle-associated membrane protein 4 (VAMP4) (Table 3). While mechanistic interactions with LRRK2 have been described in 
experimental studies for these risk genes [167,168], only SNCA and MAPT single nucleotide polymorphism (SNP) variants have been found to replicate in several studies (Table 3). Candidate gene studies of LRRK2 modifiers for risk/penetrance and AAO have been described predominantly for p.G2019S, p.G2385R, p.R1628P, and other risk variants such as DNM3 (Table 3). Six studies investigated the LRRK2 p.G2019S mutation [169-174], two studies included the LRRK2 p.G2385R [175,176] variant, two studies combined the LRRK2 p.G2385R and p.R1628P variants, which are the more common variants in the Asian population $[177,178]$. Three studies included LRRK2 noncoding and coding risk variants rs1491942 (intronic), rs7133914 (p.R1398H), and rs10878226, noncoding $2 \mathrm{~kb}$ upstream of the LRRK2 gene $[179,180]$. Of the six studies that tested SNCA noncoding variants, three studies found that SNCA rs356219 was associated with an earlier AAO for LRRK2 p.G2019S, p.G2385R, and p.R1628P in the European and Han Chinese populations $[169,173,178]$. Additionally, for noncoding variants in the MAPT gene, three of six studies showed either an association with disease risk or AAO $[170,176,181]$.

Most of these clinical genetic studies of LRRK2 modifiers have evaluated candidate genes, and such studies have been challenged for their lack of replication due to small study cohorts of LRRK2 carriers, different types of LRRK2 alleles, and various ethnic populations. There are two pressing questions in the field: why is it that not all LRRK2 variant carriers develop PD (reduced penetrance), and why can the AAO be quite variable even within families (variable age at onset). GWAS studies have nominated close to 100 genetic risk loci for PD [182-187]. With large consortium efforts, it is possible to study genetic LRRK2 modifiers with adequate statistical power [188]. While single loci only contribute to a small effect on PD risk, combining individual loci allows for the assessment of cumulative risk represented as polygenic risk scores (PRSs) and can explain $\sim 30 \%$ of the heritable risk for PD [184]. Using a PD PRS from 89 variants reported, a large cohort of heterozygous LRRK2 p.G2019S mutation carriers (833 LRRK2 p.G2019S carriers: 439 PD and 394 unaffected) was analyzed, and the PD PRS was associated with a higher penetrance of PD (OR: 1.34; $p=0.005)$. This association with PRS and penetrance was stronger in younger individuals under 55 years (OR: 1.95; $p=0.004$ ) [189]. The first GWAS study of penetrance and age-at-onset of PD among LRRK2 mutation carriers included 1879 LRRK2 mutation carriers (853 from 294 families and 1026 singletons; 96\% LRRK2 p.G2019S carriers). A variant located in the intronic region of CORO1C on chromosome 12 (rs77395454; $p=2.5 \times 10^{-8}$, beta $=1.27, \mathrm{SE}=0.23$, risk allele: $\mathrm{C}$ ) met genome-wide significance and may modify the penetrance of LRRK2 mutations [188]. In addition, a PRS derived from publicly available PD GWAS statistics was a significant predictor of penetrance, but not age of onset, suggesting that common PD-associated variants collectively increase the penetrance of LRRK2 mutations [188].

Two recent studies investigated the clinical presentation of digenic carriers of LRRK2 p.G2019S and GBA mutations and found that patients carrying mutations in both genes have milder motor and nonmotor symptoms (specifically, better olfaction) compared to GBA mutation carriers; however, cognitive scores did not differ among the groups studied. This suggests that LRRK2 p.G2019S has a potential protective role on PD motor and nonmotor phenotypes $[190,191]$. 
Table 3. Genetic modifiers of penetrance and age at onset in LRRK2 parkinsonism.

\begin{tabular}{|c|c|c|c|c|c|c|c|c|c|c|c|c|}
\hline \multirow[b]{2}{*}{$\begin{array}{l}\text { LRRK2 } \\
\text { Variants }\end{array}$} & \multirow[b]{2}{*}{ Sample Size } & \multirow[b]{2}{*}{ Population } & \multirow[b]{2}{*}{ SNCA } & \multirow[b]{2}{*}{ DNM3 } & \multicolumn{3}{|c|}{ Association with PD Risk Alleles } & \multirow[b]{2}{*}{ BST1 } & \multirow[b]{2}{*}{ Rab29/Rab7L1 } & \multirow[b]{2}{*}{ VAMP4 } & \multirow[b]{2}{*}{ PD-PRS } & \multirow[b]{2}{*}{ Ref. } \\
\hline & & & & & GAK & BDNF & MAPT & & & & & \\
\hline $\begin{array}{l}\text { rs1491942 } \\
\text { (intronic) }\end{array}$ & $\begin{array}{l}1381 \text { PD, } 1328 \\
\text { ctrl }\end{array}$ & $\begin{array}{l}\text { North } \\
\text { America, Irish, } \\
\text { Polish }\end{array}$ & rs356219, no & N/A & rs6599388 no & N/A & rs2942168 no & rs11724635 no & rs708723 no & N/A & N/A & [179] \\
\hline $\begin{array}{l}\text { rs1491942, } \\
\text { rs7133914 } \\
\text { (R1398H) }\end{array}$ & not reported & $\begin{array}{l}\text { Caucasian, } \\
\text { Asian } \\
\text { (GEOPD) }\end{array}$ & N/A & N/A & $\mathrm{N} / \mathrm{A}$ & N/A & N/A & N/A & No & N/A & $\mathrm{N} / \mathrm{A}$ & [180] \\
\hline $\begin{array}{l}\text { p.R1441C, } \\
\text { p.Y1699C, } \\
\text { p.G2019S, } \\
\text { p.I2020T }\end{array}$ & $\begin{array}{l}44 \text { carriers, } 19 \\
\text { families }\end{array}$ & $\begin{array}{l}\text { European, } \\
\text { North } \\
\text { American }\end{array}$ & No & N/A & N/A & N/A & rs2435207, AAO & N/A & N/A & N/A & N/A & [181] \\
\hline $\begin{array}{l}\text { p.G2385R, } \\
\text { p.R1628P }\end{array}$ & $\begin{array}{c}231 \mathrm{PD} \\
\text { G2385R, 65 PD } \\
\text { R1628P }\end{array}$ & Chinese & No & N/A & N/A & N/A & No & No & No & N/A & N/A & [177] \\
\hline p.G2385R & $64 \mathrm{PD}$ & Chinese & N/A & N/A & N/A & AAO & $\mathrm{N} / \mathrm{A}$ & N/A & N/A & N/A & N/A & {$[175]$} \\
\hline p.G2385R & $53 \mathrm{PD}$ & Chinese & N/A & N/A & N/A & N/A & $\begin{array}{c}\text { IVS1 }+124 \mathrm{C}>\mathrm{G} \\
\text { increased risk (major } \\
\text { allele) }\end{array}$ & $\mathrm{N} / \mathrm{A}$ & N/A & N/A & N/A & [176] \\
\hline $\begin{array}{l}\text { p.G2385R, } \\
\text { p.R1628P }\end{array}$ & $\begin{array}{l}82 \text { PD G2385R, } \\
46 \text { PD R1628P }\end{array}$ & Han Chinese & $\begin{array}{l}\text { rs356219, risk and } \\
\text { AAO (OR: 1.5) }\end{array}$ & rs2421947 No & rs1564282 No & N/A & $\mathrm{N} / \mathrm{A}$ & N/A & N/A & N/A & N/A & [178] \\
\hline p.G2019S & $84 \mathrm{PD}$ & Ashkenazi & N/A & N/A & N/A & N/A & $\begin{array}{l}\text { rs11079727, AAO } \\
\text { (older in minor allele) }\end{array}$ & N/A & N/A & N/A & N/A & [170] \\
\hline p.G2019S & $101 \mathrm{PD}$ & Arab-Berber & No & $\mathrm{N} / \mathrm{A}$ & N/A & N/A & No & N/A & $\mathrm{N} / \mathrm{A}$ & N/A & N/A & [171] \\
\hline p.G2019S & $\begin{array}{c}41 \text { families: } \\
150 \text { PD, } 103 \\
\text { unaffected, } 232 \\
\text { unrelated }\end{array}$ & Arab-Berber & N/A & $\begin{array}{c}\text { rs2421947, } \\
\text { AAO earlier } \\
\text { with GG allele }\end{array}$ & N/A & $\mathrm{N} / \mathrm{A}$ & $\mathrm{N} / \mathrm{A}$ & N/A & N/A & N/A & N/A & [172] \\
\hline p.G2019S & $\begin{array}{c}210 \mathrm{PD}, 119 \\
\text { unaffected }\end{array}$ & $\begin{array}{c}\text { European } \\
\text { (Spain) }\end{array}$ & rs356219, AAO & No & N/A & N/A & N/A & N/A & N/A & N/A & N/A & [173] \\
\hline $\begin{array}{c}\text { p.G2019S, } \\
\text { rs10878226 } \\
(2 \mathrm{~kb} \\
\text { upstream })\end{array}$ & $\begin{array}{c}724 \text { PD } \\
\text { p.G2019S, } 4882 \\
\text { PD rs10878226 }\end{array}$ & $\begin{array}{l}\text { IPDGC and } \\
\text { other }\end{array}$ & N/A & No AAO & N/A & N/A & $\mathrm{N} / \mathrm{A}$ & N/A & N/A & No & N/A & [174] \\
\hline \multirow[t]{2}{*}{ p.G2019S } & $\begin{array}{r}841 \text { (439 PD, } \\
394 \text { unaffected) }\end{array}$ & $\begin{array}{c}\text { European, } \\
\text { North America }\end{array}$ & N/A & N/A & N/A & N/A & $\mathrm{N} / \mathrm{A}$ & N/A & N/A & N/A & $\begin{array}{l}\text { P(OR: } \\
1.34)\end{array}$ & [189] \\
\hline & \multicolumn{2}{|c|}{$\begin{array}{l}\text { \# of Significant Studies (\# Total } \\
\text { Studies) }\end{array}$} & $3(6)$ & $1(4)$ & $0(2)$ & $1(1)$ & $3(6)$ & $0(2)$ & $0(3)$ & $0(1)$ & $1(1)$ & \\
\hline
\end{tabular}

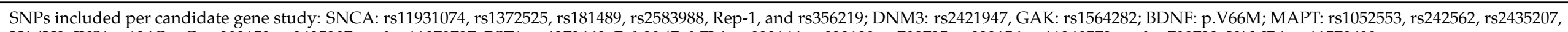

H1/H2, IVS1 + 124C > G, rs393152, rs2435207, and rs11079727; BST1: rs4273468; Rab29/Rab7L1: rs823144, rs823139, rs708725, rs823156, rs11240572, and rs708723; VAMP4: rs11578699. 


\subsection{Protective LRRK2 Variants in PD and MSA, but not for Essential Tremor or AD}

Clinical genetic studies of $L R R K 2$ as a PD risk gene also discovered variants and haplotypes that are associated with a decreased risk for developing PD. The best-studied variant is LRRK2 p.R1398H, which has been shown, in conjunction with p.N551K, to be protective for developing PD (Figure 1, Table 1). This variant was first described in a multicenter study and showed that individuals carrying the LRRK2 p.N551K and p.R1398H variants had a $20 \%$ reduced risk of developing PD [192]. These findings were replicated in several studies of Asian populations [193-196]. Additionally, a study of 177 cases with pathologically confirmed MSA and 768 controls revealed protective variants for MSA p.M2397T, p.G1624G, and p.N2081D [197]. However, while LRRK2 p.N551K and p.R1398H variants seem to have a protective effect for PD, this protective effect could not be shown for essential tremor [198] or AD [199].

LRRK2 p.R1398H affects GTPase activity, promoting axonal outgrowth and Wnt signaling activity in cell culture models; this suggests that these effects are critical for neuronal maintenance and function [73]. Induced pluripotent stem cell (iPSC) lines are being made from these protective variants, and further studies that elucidate protective mechanisms of these $L R R K 2$ variants will be critical to advancing the understanding of LRRK2 variant function [200,201].

\subsection{LRRK2 Variants in Other Neurodegenerative Diseases}

LRRK2 variants have also been tested in neurodegenerative diseases such as PSP, AD, dementia with Lewy bodies (DLB), MSA, and essential tremor; specific LRRK2 variants have also been linked to inflammatory diseases such as Crohn's disease and infectious diseases such as leprosy.

Only 1 out of 3 studies found LRRK2 variants in PSP, which included p.G2019S, p.R1441C, p.R1628P, and a novel p.A1413T variant [112,202,203]. These studies suggest that PSP can present with pathogenic $L R R K 2$ variants but at a very low frequency. A recent study has suggested a new intronic variant in the SLC2A13 gene, localized upstream of the LRRK2 gene, is associated with survival in PSP. The underlying mechanism of this association might be mediated through a long noncoding RNA-regulated effect on LRRK2 gene expression [204,205].

Furthermore, in a cohort of 772 clinical DLB patients that included cases with confirmed MSA pathology, only two pathogenic LRRK2 variants (p.G2019S and p.R1441C) were found [206]. Other studies have shown no association of $L R R K 2$ variants with MSA, assessing LRRK2 p.G2019S, p.R1628P, or p.G2385R [207-209]. No significant risk of AD for LRRK2 variants p.R1628P, p.G2385R, p.N551K, p.G2019S, and p.I2020T was detected in a meta-analysis including 13 studies [210]; additionally, no association for essential tremor (ET) risk and LRRK2 risk variants (p.L1114L, p.I1122V, p.R1441C, p.Y1699C, p.I2012T, p.G2019S, p.I2020T, and p.G2385R) has been found [211-215]. However, the only LRRK2 variant that has been associated with ET is LRRK2 p.R1628P. This study included 1277 subjects comprising 450 ET cases and 827 controls, which showed a 2-fold increased risk for ET (OR: 2.20, $p=0.0035$ ) [216].

Patients with inflammatory bowel disease (IBD) have a higher risk of developing PD [217]. A meta-analysis concluded that patients with Crohn's disease (CD) have a $28 \%$ increased risk of $\mathrm{PD}$, and, similarly, ulcerative colitis patients have a $30 \%$ increased risk of PD compared to controls [218]. Gene association studies have found a genetic link between IBD and PD through $L R R K 2$ as a common risk gene for both diseases. Similar to PD, LRRK2 p.N551K and p.R1398H variants are protective, whereas the $L R R K 2$ p.N2081D variant increases the risk for IBD $\left(\mathrm{OR} 1.6, p=2.1 \times 10^{-6}\right)$ [71].

\section{Summary and Perspective}

In the 15 years since the discovery of $L R R K 2$ mutations as a cause for PD, clinical and basic research has made enormous progress toward understanding the role of LRRK2 in PD. The work to date has been instrumental in the quest to develop PD-preventing or PD- 
modifying drugs, with LRRK2 as a target. However, these efforts are not without potential downfalls, as complete inhibition of LRRK2 induces lung pathology in nonhuman primates that also resembles LRRK2-knockout phenotypes in rodents [219,220]. Additionally, in this review, we highlight the crucial distinctions of $L R R K 2$ parkinsonism from $\mathrm{PDD}$ with respect to pathology and clinical presentation. We propose that these differences arise from the differential effects of a variety of genetic or environmental factors.

In this context, deep longitudinal profiling allowed to discern four underlying "ageotypes" or personal aging markers (liver, kidney, immunity, and metabolic dysfunctions) [221]; the balance between stress resistance or regeneration potential and environment (lifestyle, infection, microbiome, age) might be altered by LRRK2 variants in one or more groups. Such a systems approach might be necessary to gain a full understanding of the mechanisms of LRRK2 parkinsonism.

Does this present a treatment obstacle? If we approach the problem with the foreground hypothesis that differences in LRRK2 parkinsonism from iPD are the result of how different "modifiers" exert their action on LRRK2 function, then we will gain the opportunity to not only understand how asymptomatic LRRK2 carriers phenoconvert to PD but also to identify novel therapeutic targets and pathways that might even be relevant and translatable for iPD.

Author Contributions: V.G.C.-V., B.S. and R.J.N. wrote the review and prepared the tables and figures. All authors have read and agreed to the published version of the manuscript.

Funding: This work was supported by Stanford Medicine start-up funds (B.S.) and grant P30AG06651501 (B.S.), the Sergey Brin Family Foundation (R.J.N.), the Michael J. Fox Foundation 17358 (R.J.N.), the Alexander and Eva Nemeth Foundation (R.J.N.), the Farmer Family Foundation Parkinson's Research Initiative (R.J.N.), and donations in memory of Gloria Goldstein, acknowledging her love for Parkinson's patients and her hope for a cure for Parkinson's disease.

Data Availability Statement: This review used data available in publicly accessible repositories.

Conflicts of Interest: The authors declare no conflict of interest.

\section{Abbreviations}

$\begin{array}{ll}\alpha \text {-syn } & \text { Alpha-synuclein } \\ \text { A } \beta & \text { Amyloid-beta } \\ \text { AAO } & \text { Age at onset } \\ \text { ANK } & \text { Ankyrin domain } \\ \text { ARM } & \text { Armadillo domain } \\ \text { BDNF } & \text { Brain-derived neurotrophic factor } \\ \text { BST1 } & \text { Bone marrow stromal cell antigen } 1 \\ \text { CBD } & \text { Corticobasal degeneration } \\ \text { CD } & \text { Crohn's disease } \\ \text { COR } & \text { C-terminal of ROC domain } \\ \text { DLB } & \text { Dementia with Lewy bodies } \\ \text { DNM3 } & \text { Dynamin-3 } \\ \text { ET } & \text { Essential Tremor } \\ \text { GAK } & \text { Cyclin-G-associated kinase } \\ \text { GBA } & \text { Glucosidase, beta, acid, or glucocerebrosidase } \\ \text { GCI } & \text { Glia cytoplasmic inclusions } \\ \text { GTP } & \text { Guanosine triphosphate }\end{array}$




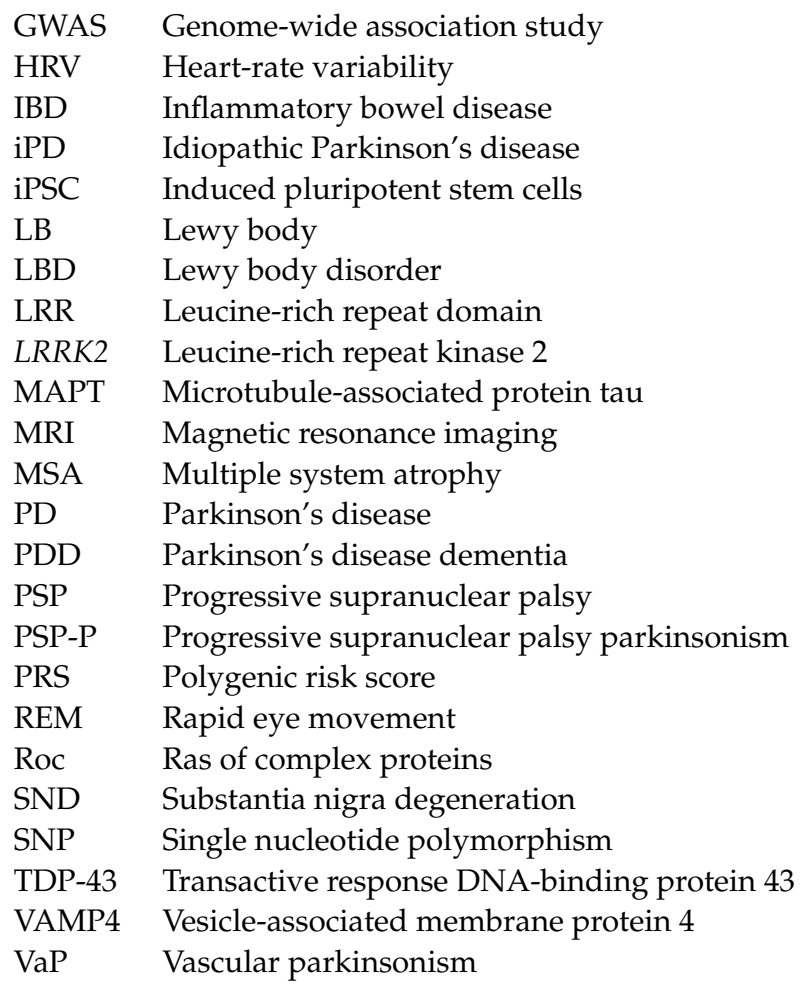

\section{References}

1. Zimprich, A.; Biskup, S.; Leitner, P.; Lichtner, P.; Farrer, M.; Lincoln, S.; Kachergus, J.; Hulihan, M.; Uitti, R.J.; Calne, D.B.; et al. Mutations in LRRK2 cause autosomal-dominant parkinsonism with pleomorphic pathology. Neuron 2004, 44, 601-607. [CrossRef] [PubMed]

2. Paisan-Ruiz, C.; Jain, S.; Evans, E.W.; Gilks, W.P.; Simon, J.; van der Brug, M.; Lopez de Munain, A.; Aparicio, S.; Gil, A.M.; Khan, N.; et al. Cloning of the gene containing mutations that cause PARK8-linked Parkinson's disease. Neuron 2004, 44, 595-600. [CrossRef] [PubMed]

3. Braak, H.; Del Tredici, K. Neuroanatomy and pathology of sporadic Parkinson's disease. Adv. Anat. Embryol. Cell Biol. 2009, 201, 1-119. [PubMed]

4. Clarke, C.E. Parkinson's disease. BMJ 2007, 335, 441-445. [CrossRef]

5. Marras, C.; Beck, J.C.; Bower, J.H.; Roberts, E.; Ritz, B.; Ross, G.W.; Abbott, R.D.; Savica, R.; Van Den Eeden, S.K.; Willis, A.W.; et al. Prevalence of Parkinson's disease across North America. NPJ Parkinsons Dis. 2018, 4, 21. [CrossRef]

6. Postuma, R.B.; Berg, D.; Stern, M.; Poewe, W.; Olanow, C.W.; Oertel, W.; Obeso, J.; Marek, K.; Litvan, I.; Lang, A.E.; et al. MDS clinical diagnostic criteria for Parkinson's disease. Mov. Disord. 2015, 30, 1591-1601. [CrossRef]

7. Postuma, R.B.; Poewe, W.; Litvan, I.; Lewis, S.; Lang, A.E.; Halliday, G.; Goetz, C.G.; Chan, P.; Slow, E.; Seppi, K.; et al. Validation of the MDS clinical diagnostic criteria for Parkinson's disease. Mov. Disord. 2018, 33, 1601-1608. [CrossRef]

8. Beach, T.G.; Adler, C.H. Importance of low diagnostic Accuracy for early Parkinson's disease. Mov. Disord. 2018, 33, 1551-1554. [CrossRef]

9. Aarsland, D.; Creese, B.; Politis, M.; Chaudhuri, K.R.; Ffytche, D.H.; Weintraub, D.; Ballard, C. Cognitive decline in Parkinson disease. Nat. Rev. Neurol. 2017, 13, 217-231. [CrossRef]

10. Pont-Sunyer, C.; Hotter, A.; Gaig, C.; Seppi, K.; Compta, Y.; Katzenschlager, R.; Mas, N.; Hofeneder, D.; Brucke, T.; Bayes, A.; et al. The onset of nonmotor symptoms in Parkinson's disease (the ONSET PD study). Mov. Disord. 2015, 30, 229-237. [CrossRef]

11. Poewe, W. Non-motor symptoms in Parkinson's disease. Eur. J. Neurol. 2008, 15 (Suppl. 1), 14-20. [CrossRef]

12. Moisan, F.; Kab, S.; Mohamed, F.; Canonico, M.; Le Guern, M.; Quintin, C.; Carcaillon, L.; Nicolau, J.; Duport, N.; Singh-Manoux, A.; et al. Parkinson disease male-to-female ratios increase with age: French nationwide study and meta-analysis. J. Neurol. Neurosurg. Psychiatry 2016, 87, 952-957. [CrossRef] [PubMed]

13. Sellbach, A.N.; Boyle, R.S.; Silburn, P.A.; Mellick, G.D. Parkinson's disease and family history. Parkinsonism Relat. Disord. 2006, 12, 399-409. [CrossRef] [PubMed]

14. Kay, D.M.; Zabetian, C.P.; Factor, S.A.; Nutt, J.G.; Samii, A.; Griffith, A.; Bird, T.D.; Kramer, P.; Higgins, D.S.; Payami, H. Parkinson's disease and LRRK2: Frequency of a common mutation in U.S. movement disorder clinics. Mov. Disord. 2006, 21, 519-523. [CrossRef] [PubMed]

15. Benamer, H.T.; de Silva, R. LRRK2 G2019S in the North African population: A review. Eur. Neurol. 2010, 63, 321-325. [CrossRef] [PubMed] 
16. Ozelius, L.J.; Senthil, G.; Saunders-Pullman, R.; Ohmann, E.; Deligtisch, A.; Tagliati, M.; Hunt, A.L.; Klein, C.; Henick, B.; Hailpern, S.M.; et al. LRRK2 G2019S as a cause of Parkinson's disease in Ashkenazi Jews. N. Engl. J. Med. 2006, 354, 424-425. [CrossRef] [PubMed]

17. Bar-Shira, A.; Hutter, C.M.; Giladi, N.; Zabetian, C.P.; Orr-Urtreger, A. Ashkenazi Parkinson's disease patients with the LRRK2 G2019S mutation share a common founder dating from the second to fifth centuries. Neurogenetics 2009, 10, 355-358. [CrossRef]

18. Zabetian, C.P.; Hutter, C.M.; Yearout, D.; Lopez, A.N.; Factor, S.A.; Griffith, A.; Leis, B.C.; Bird, T.D.; Nutt, J.G.; Higgins, D.S.; et al. LRRK2 G2019S in families with Parkinson disease who originated from Europe and the Middle East: Evidence of two distinct founding events beginning two millennia ago. Am. J. Hum. Genet. 2006, 79, 752-758. [CrossRef]

19. Monfrini, E.; Di Fonzo, A. Leucine-Rich Repeat Kinase (LRRK2) Genetics and Parkinson's Disease. Adv. Neurobiol. 2017, 14, 3-30. [CrossRef]

20. Marder, K.; Wang, Y.; Alcalay, R.N.; Mejia-Santana, H.; Tang, M.X.; Lee, A.; Raymond, D.; Mirelman, A.; Saunders-Pullman, R.; Clark, L.; et al. Age-specific penetrance of LRRK2 G2019S in the Michael J. Fox Ashkenazi Jewish LRRK2 Consortium. Neurology 2015, 85, 89-95. [CrossRef]

21. Trinh, J.; Guella, I.; Farrer, M.J. Disease Penetrance of Late-Onset Parkinsonism: A Meta-analysis. JAMA Neurol. 2014. [CrossRef] [PubMed]

22. Lee, A.J.; Wang, Y.; Alcalay, R.N.; Mejia-Santana, H.; Saunders-Pullman, R.; Bressman, S.; Corvol, J.C.; Brice, A.; Lesage, S.; Mangone, G.; et al. Penetrance estimate of LRRK2 p.G2019S mutation in individuals of non-Ashkenazi Jewish ancestry. Mov. Disord. 2017, 32, 1432-1438. [CrossRef] [PubMed]

23. Biskup, S.; West, A.B. Zeroing in on LRRK2-linked pathogenic mechanisms in Parkinson's disease. Biochim. Biophys. Acta 2009, 1792, 625-633. [CrossRef] [PubMed]

24. Blauwendraat, C.; Reed, X.; Kia, D.A.; Gan-Or, Z.; Lesage, S.; Pihlstrom, L.; Guerreiro, R.; Gibbs, J.R.; Sabir, M.; Ahmed, S.; et al. Frequency of Loss of Function Variants in LRRK2 in Parkinson Disease. JAMA Neurol. 2018, 75, 1416-1422. [CrossRef]

25. Whiffin, N.; Armean, I.M.; Kleinman, A.; Marshall, J.L.; Minikel, E.V.; Goodrich, J.K.; Quaife, N.M.; Cole, J.B.; Wang, Q.; Karczewski, K.J.; et al. The effect of LRRK2 loss-of-function variants in humans. Nat. Med. 2020, 26, 869-877. [CrossRef] [PubMed]

26. Shu, L.; Zhang, Y.; Sun, Q.; Pan, H.; Tang, B. A Comprehensive Analysis of Population Differences in LRRK2 Variant Distribution in Parkinson's Disease. Front. Aging Neurosci. 2019, 11, 13. [CrossRef]

27. Jaleel, M.; Nichols, R.J.; Deak, M.; Campbell, D.G.; Gillardon, F.; Knebel, A.; Alessi, D.R. LRRK2 phosphorylates moesin at threonine-558: Characterization of how Parkinson's disease mutants affect kinase activity. Biochem. J. 2007, 405, 307-317. [CrossRef]

28. Nichols, R.J.; Dzamko, N.; Morrice, N.A.; Campbell, D.G.; Deak, M.; Ordureau, A.; Macartney, T.; Tong, Y.; Shen, J.; Prescott, A.R.; et al. 14-3-3 binding to LRRK2 is disrupted by multiple Parkinson's disease-associated mutations and regulates cytoplasmic localization. Biochem. J. 2010, 430, 393-404. [CrossRef]

29. Li, X.; Wang, Q.J.; Pan, N.; Lee, S.; Zhao, Y.; Chait, B.T.; Yue, Z. Phosphorylation-dependent 14-3-3 binding to LRRK2 is impaired by common mutations of familial Parkinson's disease. PLoS ONE 2011, 6, e17153. [CrossRef]

30. Zhang, P.; Fan, Y.; Ru, H.; Wang, L.; Magupalli, V.G.; Taylor, S.S.; Alessi, D.R.; Wu, H. Crystal structure of the WD40 domain dimer of LRRK2. Proc. Natl. Acad. Sci. USA 2019, 116, 1579-1584. [CrossRef]

31. Marin, I.; van Egmond, W.N.; van Haastert, P.J. The Roco protein family: A functional perspective. FASEB J. Off. Publ. Fed. Am. Soc. Exp. Biol. 2008, 22, 3103-3110. [CrossRef] [PubMed]

32. Lewis, P.A. The function of ROCO proteins in health and disease. Biol. Cell 2009, 101, 183-191. [CrossRef] [PubMed]

33. Liao, J.; Wu, C.X.; Burlak, C.; Zhang, S.; Sahm, H.; Wang, M.; Zhang, Z.Y.; Vogel, K.W.; Federici, M.; Riddle, S.M.; et al. Parkinson disease-associated mutation R1441H in LRRK2 prolongs the "active state" of its GTPase domain. Proc. Natl. Acad. Sci. USA 2014. [CrossRef] [PubMed]

34. Deng, J.; Lewis, P.A.; Greggio, E.; Sluch, E.; Beilina, A.; Cookson, M.R. Structure of the ROC domain from the Parkinson's disease-associated leucine-rich repeat kinase 2 reveals a dimeric GTPase. Proc. Natl. Acad. Sci. USA 2008, 105, 1499-1504. [CrossRef]

35. Rudi, K.; Ho, F.Y.; Gilsbach, B.K.; Pots, H.; Wittinghofer, A.; Kortholt, A.; Klare, J.P. Conformational heterogeneity of the Roc domains in C. tepidum Roc-COR and implications for human LRRK2 Parkinson mutations. Biosci. Rep. 2015, 35. [CrossRef]

36. Gotthardt, K.; Weyand, M.; Kortholt, A.; Van Haastert, P.J.; Wittinghofer, A. Structure of the Roc-COR domain tandem of C. tepidum, a prokaryotic homologue of the human LRRK2 Parkinson kinase. EMBO J. 2008, 27, 2352. [CrossRef]

37. Jorgensen, N.D.; Peng, Y.; Ho, C.C.; Rideout, H.J.; Petrey, D.; Liu, P.; Dauer, W.T. The WD40 domain is required for LRRK2 neurotoxicity. PLoS ONE 2009, 4, e8463. [CrossRef]

38. Greggio, E.; Zambrano, I.; Kaganovich, A.; Beilina, A.; Taymans, J.M.; Daniels, V.; Lewis, P.; Jain, S.; Ding, J.; Syed, A.; et al. The Parkinson disease-associated leucine-rich repeat kinase 2 (LRRK2) is a dimer that undergoes intramolecular autophosphorylation. J. Biol. Chem. 2008, 283, 16906-16914. [CrossRef]

39. Langston, J.W.; Schüle, B.; Rees, L.; Nichols, R.J.; Barlow, C. Multisystem Lewy body disease and the other parkinsonian disorders. Nat. Genet. 2015, 47, 1378-1384. [CrossRef]

40. Lin, M.K.; Farrer, M.J. Genetics and genomics of Parkinson's disease. Genome Med. 2014, 6, 48. [CrossRef]

41. Mata, I.F.; Wedemeyer, W.J.; Farrer, M.J.; Taylor, J.P.; Gallo, K.A. LRRK2 in Parkinson's disease: Protein domains and functional insights. Trends Neurosci. 2006, 29, 286-293. [CrossRef] [PubMed] 
42. Steger, M.; Tonelli, F.; Ito, G.; Davies, P.; Trost, M.; Vetter, M.; Wachter, S.; Lorentzen, E.; Duddy, G.; Wilson, S.; et al. Phosphoproteomics reveals that Parkinson's disease kinase LRRK2 regulates a subset of Rab GTPases. Elife 2016, 5, 12813. [CrossRef] [PubMed]

43. Hanks, S.K.; Hunter, T. Protein kinases 6. The eukaryotic protein kinase superfamily: Kinase (catalytic) domain structure and classification. FASEB J. Off. Publ. Fed. Am. Soc. Exp. Biol. 1995, 9, 576-596.

44. Hanks, S.K.; Quinn, A.M. Protein kinase catalytic domain sequence database: Identification of conserved features of primary structure and classification of family members. Methods Enzymol. 1991, 200, 38-62. [PubMed]

45. Hanks, S.K.; Quinn, A.M.; Hunter, T. The protein kinase family: Conserved features and deduced phylogeny of the catalytic domains. Science 1988, 241, 42-52. [CrossRef]

46. Greggio, E.; Cookson, M.R. Leucine-rich repeat kinase 2 mutations and Parkinson's disease: Three questions. ASN Neuro 2009, 1. [CrossRef]

47. Schmidt, S.H.; Knape, M.J.; Boassa, D.; Mumdey, N.; Kornev, A.P.; Ellisman, M.H.; Taylor, S.S.; Herberg, F.W. The dynamic switch mechanism that leads to activation of LRRK2 is embedded in the DFGpsi motif in the kinase domain. Proc. Natl. Acad. Sci. USA 2019, 116, 14979-14988. [CrossRef]

48. Gilsbach, B.K.; Ho, F.Y.; Vetter, I.R.; van Haastert, P.J.; Wittinghofer, A.; Kortholt, A. Roco kinase structures give insights into the mechanism of Parkinson disease-related leucine-rich-repeat kinase 2 mutations. Proc. Natl. Acad. Sci. USA 2012, 109, 10322-10327. [CrossRef]

49. Gilsbach, B.K.; Kortholt, A. Structural biology of the LRRK2 GTPase and kinase domains: Implications for regulation. Front. Mol. Neurosci. 2014, 7, 32. [CrossRef]

50. Gloeckner, C.J.; Kinkl, N.; Schumacher, A.; Braun, R.J.; O’Neill, E.; Meitinger, T.; Kolch, W.; Prokisch, H.; Ueffing, M. The Parkinson disease causing LRRK2 mutation I2020T is associated with increased kinase activity. Hum. Mol. Genet. 2006, 15, 223-232. [CrossRef]

51. Nichols, R.J.; Dzamko, N.; Hutti, J.E.; Cantley, L.C.; Deak, M.; Moran, J.; Bamborough, P.; Reith, A.D.; Alessi, D.R. Substrate specificity and inhibitors of LRRK2, a protein kinase mutated in Parkinson's disease. Biochem. J. 2009, 424, 47-60. [CrossRef] [PubMed]

52. Ray, S.; Bender, S.; Kang, S.; Lin, R.; Glicksman, M.A.; Liu, M. The Parkinson disease-linked LRRK2 protein mutation I2020T stabilizes an active state conformation leading to increased kinase activity. J. Biol. Chem. 2014, 289, 13042-13053. [CrossRef] [PubMed]

53. Rudenko, I.N.; Kaganovich, A.; Hauser, D.N.; Beylina, A.; Chia, R.; Ding, J.; Maric, D.; Jaffe, H.; Cookson, M.R. The G2385R variant of leucine-rich repeat kinase 2 associated with Parkinson's disease is a partial loss-of-function mutation. Biochem. J. 2012, 446, 99-111. [CrossRef] [PubMed]

54. Leandrou, E.; Markidi, E.; Memou, A.; Melachroinou, K.; Greggio, E.; Rideout, H.J. Kinase activity of mutant LRRK2 manifests differently in hetero-dimeric vs. homo-dimeric complexes. Biochem. J. 2019, 476, 559-579. [CrossRef]

55. Kalia, L.V.; Lang, A.E.; Hazrati, L.N.; Fujioka, S.; Wszolek, Z.K.; Dickson, D.W.; Ross, O.A.; Van Deerlin, V.M.; Trojanowski, J.Q.; Hurtig, H.I.; et al. Clinical correlations with Lewy body pathology in LRRK2-related Parkinson disease. JAMA Neurol. 2015, 72, 100-105. [CrossRef]

56. Henderson, M.X.; Sengupta, M.; Trojanowski, J.Q.; Lee, V.M.Y. Alzheimer's disease tau is a prominent pathology in LRRK2 Parkinson's disease. Acta Neuropathol. Commun. 2019, 7, 183. [CrossRef]

57. Takanashi, M.; Funayama, M.; Matsuura, E.; Yoshino, H.; Li, Y.; Tsuyama, S.; Takashima, H.; Nishioka, K.; Hattori, N. Isolated nigral degeneration without pathological protein aggregation in autopsied brains with LRRK2 p.R1441H homozygous and heterozygous mutations. Acta Neuropathol. Commun. 2018, 6, 105. [CrossRef]

58. Lee, K.; Nguyen, K.D.; Sun, C.; Liu, M.; Zafar, F.; Saetern, J.; Flierl, A.; Tetrud, J.W.; Langston, J.W.; Dickson, D.; et al. LRRK2 p.Ile1371Val Mutation in a Case with Neuropathologically Confirmed Multi-System Atrophy. J. Parkinsons Dis. 2018, 8, 93-100. [CrossRef]

59. Schneider, S.A.; Alcalay, R.N. Neuropathology of genetic synucleinopathies with parkinsonism: Review of the literature. Mov. Disord. 2017, 32, 1504-1523. [CrossRef]

60. Ysselstein, D.; Nguyen, M.; Young, T.J.; Severino, A.; Schwake, M.; Merchant, K.; Krainc, D. LRRK2 kinase activity regulates lysosomal glucocerebrosidase in neurons derived from Parkinson's disease patients. Nat. Commun. 2019, 10, 5570. [CrossRef]

61. Bonet-Ponce, L.; Beilina, A.; Williamson, C.D.; Lindberg, E.; Kluss, J.H.; Saez-Atienzar, S.; Landeck, N.; Kumaran, R.; Mamais, A.; Bleck, C.K.E.; et al. LRRK2 mediates tubulation and vesicle sorting from lysosomes. Sci. Adv. 2020, 6. [CrossRef] [PubMed]

62. Manzoni, C.; Lewis, P.A. LRRK2 and Autophagy. Adv. Neurobiol. 2017, 14, 89-105. [CrossRef] [PubMed]

63. Kim, C.; Beilina, A.; Smith, N.; Li, Y.; Kim, M.; Kumaran, R.; Kaganovich, A.; Mamais, A.; Adame, A.; Iba, M.; et al. LRRK2 mediates microglial neurotoxicity via NFATc2 in rodent models of synucleinopathies. Sci. Transl. Med. 2020, 12. [CrossRef] [PubMed]

64. Wallings, R.L.; Herrick, M.K.; Tansey, M.G. LRRK2 at the Interface Between Peripheral and Central Immune Function in Parkinson's. Front. Neurosci. 2020, 14, 443. [CrossRef]

65. Ahmadi Rastegar, D.; Dzamko, N. Leucine Rich Repeat Kinase 2 and Innate Immunity. Front. Neurosci. 2020, 14. [CrossRef] 
66. Howlett, E.H.; Jensen, N.; Belmonte, F.; Zafar, F.; Hu, X.; Kluss, J.; Schüle, B.; Kaufman, B.A.; Greenamyre, J.T.; Sanders, L.H. LRRK2 G2019S-induced mitochondrial DNA damage is LRRK2 kinase dependent and inhibition restores mtDNA integrity in Parkinson's disease. Hum. Mol. Genet. 2017, 26, 4340-4351. [CrossRef]

67. Singh, A.; Zhi, L.; Zhang, H. LRRK2 and mitochondria: Recent advances and current views. Brain Res. 2019, 1702, 96-104. [CrossRef]

68. Wang, S.; Kelly, K.; Brotchie, J.M.; Koprich, J.B.; West, A.B. Exosome markers of LRRK2 kinase inhibition. NPJ Parkinson's Dis. 2020, 6, 32. [CrossRef]

69. Candelario, K.M.; Balaj, L.; Zheng, T.; Skog, J.; Scheffler, B.; Breakefield, X.; Schüle, B.; Steindler, D.A. Exosome/Microvesicle Content is Altered in LRRK2 Mutant iPSC-derived Neural Cells. J. Comp. Neurol. 2019. [CrossRef]

70. Christensen, K.V.; Hentzer, M.; Oppermann, F.S.; Elschenbroich, S.; Dossang, P.; Thirstrup, K.; Egebjerg, J.; Williamson, D.S.; Smith, G.P. LRRK2 exonic variants associated with Parkinson's disease augment phosphorylation levels for LRRK2-Ser1292 and Rab10-Thr73. bioRxiv 2018, 447946. [CrossRef]

71. Hui, K.Y.; Fernandez-Hernandez, H.; Hu, J.; Schaffner, A.; Pankratz, N.; Hsu, N.Y.; Chuang, L.S.; Carmi, S.; Villaverde, N.; Li, X.; et al. Functional variants in the LRRK2 gene confer shared effects on risk for Crohn's disease and Parkinson's disease. Sci. Transl. Med. 2018, 10. [CrossRef] [PubMed]

72. West, A.B.; Moore, D.J.; Choi, C.; Andrabi, S.A.; Li, X.; Dikeman, D.; Biskup, S.; Zhang, Z.; Lim, K.L.; Dawson, V.L.; et al. Parkinson's disease-associated mutations in LRRK2 link enhanced GTP-binding and kinase activities to neuronal toxicity. Hum. Mol. Genet. 2007, 16, 223-232. [CrossRef]

73. Nixon-Abell, J.; Berwick, D.C.; Granno, S.; Spain, V.A.; Blackstone, C.; Harvey, K. Protective LRRK2 R1398H Variant Enhances GTPase and Wnt Signaling Activity. Front. Mol. Neurosci. 2016, 9, 18. [CrossRef] [PubMed]

74. Aasly, J.O.; Vilariño-Güell, C.; Dachsel, J.C.; Webber, P.J.; West, A.B.; Haugarvoll, K.; Johansen, K.K.; Toft, M.; Nutt, J.G.; Payami, H.; et al. Novel pathogenic LRRK2 p.Asn1437His substitution in familial Parkinson's disease. Mov. Disord. 2010, 25, $2156-2163$. [CrossRef] [PubMed]

75. West, A.B.; Moore, D.J.; Biskup, S.; Bugayenko, A.; Smith, W.W.; Ross, C.A.; Dawson, V.L.; Dawson, T.M. Parkinson's diseaseassociated mutations in leucine-rich repeat kinase 2 augment kinase activity. Proc. Natl. Acad. Sci. USA 2005, 102, 16842-16847. [CrossRef] [PubMed]

76. Lewis, P.A.; Greggio, E.; Beilina, A.; Jain, S.; Baker, A.; Cookson, M.R. The R1441C mutation of LRRK2 disrupts GTP hydrolysis. Biochem. Biophys. Res. Commun. 2007, 357, 668-671. [CrossRef]

77. Shu, Y.; Ming, J.; Zhang, P.; Wang, Q.; Jiao, F.; Tian, B. Parkinson-Related LRRK2 Mutation R1628P Enables Cdk5 Phosphorylation of LRRK2 and Upregulates Its Kinase Activity. PLoS ONE 2016, 11, e0149739. [CrossRef]

78. Fava, V.M.; Xu, Y.Z.; Lettre, G.; Van Thuc, N.; Orlova, M.; Thai, V.H.; Tao, S.; Croteau, N.; Eldeeb, M.A.; MacDougall, E.J.; et al. Pleiotropic effects for Parkin and LRRK2 in leprosy type-1 reactions and Parkinson's disease. Proc. Natl. Acad. Sci. USA 2019, 116, 15616-15624. [CrossRef]

79. Daniëls, V.; Vancraenenbroeck, R.; Law, B.M.; Greggio, E.; Lobbestael, E.; Gao, F.; De Maeyer, M.; Cookson, M.R.; Harvey, K.; Baekelandt, V.; et al. Insight into the mode of action of the LRRK2 Y1699C pathogenic mutant. J. Neurochem. 2011, 116, 304-315. [CrossRef]

80. Ikezu, T.; Koro, L.; Wolozin, B.; Farraye, F.A.; Strongosky, A.J.; Wszolek, Z.K. Crohn's and Parkinson's Disease-Associated LRRK2 Mutations Alter Type II Interferon Responses in Human CD14(+) Blood Monocytes Ex Vivo. J. Neuroimmune Pharmacol. 2020, 15, 794-800. [CrossRef]

81. Fava, V.M.; Manry, J.; Cobat, A.; Orlova, M.; Van Thuc, N.; Ba, N.N.; Thai, V.H.; Abel, L.; Alcais, A.; Schurr, E.; et al. A Missense LRRK2 Variant Is a Risk Factor for Excessive Inflammatory Responses in Leprosy. PLoS Negl. Trop. Dis. 2016, 10, e0004412. [CrossRef] [PubMed]

82. Liu, Z.; Lee, J.; Krummey, S.; Lu, W.; Cai, H.; Lenardo, M.J. The kinase LRRK2 is a regulator of the transcription factor NFAT that modulates the severity of inflammatory bowel disease. Nat. Immunol. 2011, 12, 1063-1070. [CrossRef] [PubMed]

83. Marras, C.; Schüle, B.; Munhoz, R.P.; Rogaeva, E.; Langston, J.W.; Kasten, M.; Meaney, C.; Klein, C.; Wadia, P.M.; Lim, S.Y.; et al. Phenotype in parkinsonian and nonparkinsonian LRRK2 G2019S mutation carriers. Neurology 2011, 77, 325-333. [CrossRef] [PubMed]

84. Shu, L.; Zhang, Y.; Pan, H.; Xu, Q.; Guo, J.; Tang, B.; Sun, Q. Clinical Heterogeneity Among LRRK2 Variants in Parkinson's Disease: A Meta-Analysis. Front. Aging Neurosci. 2018, 10, 283. [CrossRef]

85. Orr-Urtreger, A.; Shifrin, C.; Rozovski, U.; Rosner, S.; Bercovich, D.; Gurevich, T.; Yagev-More, H.; Bar-Shira, A.; Giladi, N. The LRRK2 G2019S mutation in Ashkenazi Jews with Parkinson disease: Is there a gender effect? Neurology 2007, 69, 1595-1602. [CrossRef]

86. Saunders-Pullman, R.; Mirelman, A.; Alcalay, R.N.; Wang, C.; Ortega, R.A.; Raymond, D.; Mejia-Santana, H.; Orbe-Reilly, M.; Johannes, B.A.; Thaler, A.; et al. Progression in the LRRK2-Asssociated Parkinson Disease Population. JAMA Neurol. 2018, 75, 312-319. [CrossRef]

87. Mestre, T.A.; Pont-Sunyer, C.; Kausar, F.; Visanji, N.P.; Ghate, T.; Connolly, B.S.; Gasca-Salas, C.; Kern, D.S.; Jain, J.; Slow, E.J.; et al. Clustering of motor and nonmotor traits in leucine-rich repeat kinase 2 G2019S Parkinson's disease nonparkinsonian relatives: A multicenter family study. Mov. Disord. 2018, 33, 960-965. [CrossRef] 
88. Joers, V.; Emborg, M.E. Modeling and imaging cardiac sympathetic neurodegeneration in Parkinson's disease. Am. J. Nucl. Med. Mol. Imaging 2014, 4, 125-159.

89. Alonso, A.; Huang, X.; Mosley, T.H.; Heiss, G.; Chen, H. Heart rate variability and the risk of Parkinson disease: The Atherosclerosis Risk in Communities study. Ann. Neurol. 2015, 77, 877-883. [CrossRef]

90. Visanji, N.P.; Bhudhikanok, G.S.; Mestre, T.A.; Ghate, T.; Udupa, K.; AlDakheel, A.; Connolly, B.S.; Gasca-Salas, C.; Kern, D.S.; Jain, J.; et al. Heart rate variability in leucine-rich repeat kinase 2-associated Parkinson's disease. Mov. Disord. 2017, 32, 610-614. [CrossRef]

91. Carricarte Naranjo, C.; Marras, C.; Visanji, N.P.; Cornforth, D.J.; Sanchez-Rodriguez, L.; Schule, B.; Goldman, S.M.; Estevez, M.; Stein, P.K.; Lang, A.E.; et al. Increased markers of cardiac vagal activity in leucine-rich repeat kinase 2-associated Parkinson's disease. Clin. Auton Res. 2019, 29, 603-614. [CrossRef] [PubMed]

92. Helmich, R.C.; Thaler, A.; van Nuenen, B.F.; Gurevich, T.; Mirelman, A.; Marder, K.S.; Bressman, S.; Orr-Urtreger, A.; Giladi, N.; Bloem, B.R.; et al. Reorganization of corticostriatal circuits in healthy G2019S LRRK2 carriers. Neurology 2015, 84, 399-406. [CrossRef] [PubMed]

93. Jacob, Y.; Rosenberg-Katz, K.; Gurevich, T.; Helmich, R.C.; Bloem, B.R.; Orr-Urtreger, A.; Giladi, N.; Mirelman, A.; Hendler, T.; Thaler, A. Network abnormalities among non-manifesting Parkinson disease related LRRK2 mutation carriers. Hum. Brain Mapp. 2019, 40, 2546-2555. [CrossRef] [PubMed]

94. Vilas, D.; Segura, B.; Baggio, H.C.; Pont-Sunyer, C.; Compta, Y.; Valldeoriola, F.; Jose Marti, M.; Quintana, M.; Bayes, A.; Hernandez-Vara, J.; et al. Nigral and striatal connectivity alterations in asymptomatic LRRK2 mutation carriers: A magnetic resonance imaging study. Mov. Disord. 2016, 31, 1820-1828. [CrossRef]

95. Thaler, A.; Mirelman, A.; Helmich, R.C.; van Nuenen, B.F.; Rosenberg-Katz, K.; Gurevich, T.; Orr-Urtreger, A.; Marder, K.; Bressman, S.; Bloem, B.R.; et al. Neural correlates of executive functions in healthy G2019S LRRK2 mutation carriers. Cortex 2013, 49, 2501-2511. [CrossRef]

96. Thaler, A.; Gonen, T.; Mirelman, A.; Helmich, R.C.; Gurevich, T.; Orr-Urtreger, A.; Bloem, B.R.; Giladi, N.; Hendler, T.; Consortium, L.A.J. Altered reward-related neural responses in non-manifesting carriers of the Parkinson disease related LRRK2 mutation. Brain Imaging Behav. 2019, 13, 1009-1020. [CrossRef]

97. Liu, S.Y.; Wile, D.J.; Fu, J.F.; Valerio, J.; Shahinfard, E.; McCormick, S.; Mabrouk, R.; Vafai, N.; McKenzie, J.; Neilson, N.; et al. The effect of LRRK2 mutations on the cholinergic system in manifest and premanifest stages of Parkinson's disease: A cross-sectional PET study. Lancet Neurol. 2018, 17, 309-316. [CrossRef]

98. Dickson, D.W. Neuropathology of Parkinson disease. Parkinsonism Relat. Disord. 2018, 46 (Suppl. 1), S30-S33. [CrossRef]

99. Braak, H.; Del Tredici, K. Neuropathological Staging of Brain Pathology in Sporadic Parkinson's disease: Separating the Wheat from the Chaff. J. Parkinsons Dis. 2017, 7, S71-S85. [CrossRef]

100. Karanth, S.; Nelson, P.T.; Katsumata, Y.; Kryscio, R.J.; Schmitt, F.A.; Fardo, D.W.; Cykowski, M.D.; Jicha, G.A.; Van Eldik, L.J.; Abner, E.L. Prevalence and Clinical Phenotype of Quadruple Misfolded Proteins in Older Adults. JAMA Neurol. 2020. [CrossRef]

101. Poulopoulos, M.; Levy, O.A.; Alcalay, R.N. The neuropathology of genetic Parkinson's disease. Mov. Disord. 2012, 27, 831-842. [CrossRef] [PubMed]

102. Poulopoulos, M.; Cortes, E.; Vonsattel, J.P.; Fahn, S.; Waters, C.; Cote, L.J.; Moskowitz, C.; Honig, L.S.; Clark, L.N.; Marder, K.S.; et al. Clinical and pathological characteristics of LRRK2 G2019S patients with PD. J. Mol. Neurosci. 2012, 47, 139-143. [CrossRef] [PubMed]

103. Agin-Liebes, J.; Cortes, E.; Vonsattel, J.P.; Marder, K.; Alcalay, R.N. Movement disorders rounds: A case of missing pathology in a patient with LRRK2 Parkinson's disease. Parkinsonism Relat. Disord. 2019. [CrossRef] [PubMed]

104. Hasegawa, K.; Stoessl, A.J.; Yokoyama, T.; Kowa, H.; Wszolek, Z.K.; Yagishita, S. Familial parkinsonism: Study of original Sagamihara PARK8 (I2020T) kindred with variable clinicopathologic outcomes. Parkinsonism Relat. Disord. 2009, 15, 300-306. [CrossRef] [PubMed]

105. Riboldi, G.M.; Palma, J.A.; Cortes, E.; Iida, M.A.; Sikder, T.; Henderson, B.; Raj, T.; Walker, R.H.; Crary, J.F.; Kaufmann, H.; et al. Early-onset pathologically proven multiple system atrophy with LRRK2 G2019S mutation. Mov. Disord. 2019, 34, $1080-1082$. [CrossRef] [PubMed]

106. Huang, Y.; Song, Y.J.; Murphy, K.; Holton, J.L.; Lashley, T.; Revesz, T.; Gai, W.P.; Halliday, G.M. LRRK2 and parkin immunoreactivity in multiple system atrophy inclusions. Acta Neuropathol. 2008, 116, 639-646. [CrossRef]

107. Ling, H.; Kara, E.; Bandopadhyay, R.; Hardy, J.; Holton, J.; Xiromerisiou, G.; Lees, A.; Houlden, H.; Revesz, T. TDP-43 pathology in a patient carrying G2019S LRRK2 mutation and a novel p.Q124E MAPT. Neurobiol. Aging 2013, 34, 2889.e5-2889.e9. [CrossRef]

108. Vilas, D.; Sharp, M.; Gelpi, E.; Genis, D.; Marder, K.S.; Cortes, E.; Vonsattel, J.P.; Tolosa, E.; Alcalay, R.N. Clinical and neuropathological features of progressive supranuclear palsy in Leucine rich repeat kinase (LRRK2) G2019S mutation carriers. Mov. Disord. 2018, 33, 335-338. [CrossRef]

109. Ujiie, S.; Hatano, T.; Kubo, S.; Imai, S.; Sato, S.; Uchihara, T.; Yagishita, S.; Hasegawa, K.; Kowa, H.; Sakai, F.; et al. LRRK2 I2020T mutation is associated with tau pathology. Parkinsonism Relat. Disord. 2012, 18, 819-823. [CrossRef]

110. Blauwendraat, C.; Pletnikova, O.; Geiger, J.T.; Murphy, N.A.; Abramzon, Y.; Rudow, G.; Mamais, A.; Sabir, M.S.; Crain, B.; Ahmed, S.; et al. Genetic analysis of neurodegenerative diseases in a pathology cohort. Neurobiol. Aging 2019, 76, 214.e1-214.e9. [CrossRef] 
111. Wszolek, Z.K.; Pfeiffer, R.F.; Tsuboi, Y.; Uitti, R.J.; McComb, R.D.; Stoessl, A.J.; Strongosky, A.J.; Zimprich, A.; Muller-Myhsok, B.; Farrer, M.J.; et al. Autosomal dominant parkinsonism associated with variable synuclein and tau pathology. Neurology 2004, 62, 1619-1622. [CrossRef] [PubMed]

112. Sanchez-Contreras, M.; Heckman, M.G.; Tacik, P.; Diehl, N.; Brown, P.H.; Soto-Ortolaza, A.I.; Christopher, E.A.; Walton, R.L.; Ross, O.A.; Golbe, L.I.; et al. Study of LRRK2 variation in tauopathy: Progressive supranuclear palsy and corticobasal degeneration. Mov. Disord. 2017, 32, 115-123. [CrossRef] [PubMed]

113. Giordana, M.T.; D’Agostino, C.; Albani, G.; Mauro, A.; Di Fonzo, A.; Antonini, A.; Bonifati, V. Neuropathology of Parkinson's disease associated with the LRRK2 Ile1371Val mutation. Mov. Disord. 2007, 22, 275-278. [CrossRef] [PubMed]

114. Puschmann, A.; Englund, E.; Ross, O.A.; Vilarino-Guell, C.; Lincoln, S.J.; Kachergus, J.M.; Cobb, S.A.; Tornqvist, A.L.; Rehncrona, S.; Widner, H.; et al. First neuropathological description of a patient with Parkinson's disease and LRRK2 p.N1437H mutation. Parkinsonism Relat. Disord. 2012, 18, 332-338. [CrossRef] [PubMed]

115. Marti-Masso, J.F.; Ruiz-Martinez, J.; Bolano, M.J.; Ruiz, I.; Gorostidi, A.; Moreno, F.; Ferrer, I.; Lopez de Munain, A. Neuropathology of Parkinson's disease with the R1441G mutation in LRRK2. Mov. Disord. 2009, 24, 1998-2001. [CrossRef] [PubMed]

116. Wszolek, Z.K.; Pfeiffer, B.; Fulgham, J.R.; Parisi, J.E.; Thompson, B.M.; Uitti, R.J.; Calne, D.B.; Pfeiffer, R.F. Western Nebraska family (family D) with autosomal dominant parkinsonism. Neurology 1995, 45, 502-505. [CrossRef] [PubMed]

117. Khan, N.L.; Jain, S.; Lynch, J.M.; Pavese, N.; Abou-Sleiman, P.; Holton, J.L.; Healy, D.G.; Gilks, W.P.; Sweeney, M.G.; Ganguly, M.; et al. Mutations in the gene LRRK2 encoding dardarin (PARK8) cause familial Parkinson's disease: Clinical, pathological, olfactory and functional imaging and genetic data. Brain 2005, 128, 2786-2796. [CrossRef]

118. Wszolek, Z.K.; Vieregge, P.; Uitti, R.J.; Gasser, T.; Yasuhara, O.; McGeer, P.; Berry, K.; Calne, D.B.; Vingerhoets, F.J.; Klein, C.; et al. German-Canadian family (family A) with parkinsonism, amyotrophy, and dementia-Longitudinal observations. Parkinsonism Relat. Disord. 1997, 3, 125-139. [CrossRef]

119. Giasson, B.I.; Covy, J.P.; Bonini, N.M.; Hurtig, H.I.; Farrer, M.J.; Trojanowski, J.Q.; Van Deerlin, V.M. Biochemical and pathological characterization of Lrrk2. Ann. Neurol. 2006, 59, 315-322. [CrossRef]

120. Gaig, C.; Marti, M.J.; Ezquerra, M.; Rey, M.J.; Cardozo, A.; Tolosa, E. G2019S LRRK2 mutation causing Parkinson's disease without Lewy bodies. J. Neurol. Neurosurg. Psychiatry 2007, 78, 626-628. [CrossRef]

121. Gaig, C.; Ezquerra, M.; Marti, M.J.; Valldeoriola, F.; Munoz, E.; Llado, A.; Rey, M.J.; Cardozo, A.; Molinuevo, J.L.; Tolosa, E. Screening for the LRRK2 G2019S and codon-1441 mutations in a pathological series of parkinsonian syndromes and frontotemporal lobar degeneration. J. Neurol. Sci. 2008, 270, 94-98. [CrossRef] [PubMed]

122. Hasegawa, K.; Kowa, H. Autosomal Dominant Familial Parkinson Disease: Older Onset of Age, and Good Response to Levodopa Therapy. Eur. Neurol. 1997, 38 (Suppl. 1), 39-43. [CrossRef] [PubMed]

123. Funayama, M.; Hasegawa, K.; Kowa, H.; Saito, M.; Tsuji, S.; Obata, F. A new locus for Parkinson's disease (PARK8) maps to chromosome 12p11.2-q13.1. Ann. Neurol. 2002, 51, 296-301. [CrossRef] [PubMed]

124. Covy, J.P.; Yuan, W.; Waxman, E.A.; Hurtig, H.I.; Van Deerlin, V.M.; Giasson, B.I. Clinical and pathological characteristics of patients with leucine-rich repeat kinase-2 mutations. Mov. Disord. 2009, 24, 32-39. [CrossRef]

125. Jellinger, K.A.; Seppi, K.; Wenning, G.K.; Poewe, W. Impact of coexistent Alzheimer pathology on the natural history of Parkinson's disease. J. Neural. Transm. (Vienna) 2002, 109, 329-339. [CrossRef]

126. Melrose, H.L.; Dächsel, J.C.; Behrouz, B.; Lincoln, S.J.; Yue, M.; Hinkle, K.M.; Kent, C.B.; Korvatska, E.; Taylor, J.P.; Witten, L.; et al Impaired dopaminergic neurotransmission and microtubule-associated protein tau alterations in human LRRK2 transgenic mice. Neurobiol. Dis. 2010, 40, 503-517. [CrossRef]

127. Goldman, S.M. Environmental toxins and Parkinson's disease. Annu. Rev. Pharmacol. Toxicol. 2014, 54, 141-164. [CrossRef]

128. Simon, D.K.; Tanner, C.M.; Brundin, P. Parkinson Disease Epidemiology, Pathology, Genetics, and Pathophysiology. Clin. Geriatr Med. 2020, 36, 1-12. [CrossRef]

129. Caudle, W.M.; Guillot, T.S.; Lazo, C.R.; Miller, G.W. Industrial toxicants and Parkinson's disease. Neurotoxicology 2012, 33, 178-188. [CrossRef]

130. Tanner, C.M. Advances in environmental epidemiology. Mov. Disord. 2010, 25 (Suppl. 1), S58-S62. [CrossRef]

131. Gubert, C.; Kong, G.; Renoir, T.; Hannan, A.J. Exercise, diet and stress as modulators of gut microbiota: Implications for neurodegenerative diseases. Neurobiol. Dis. 2020, 134, 104621. [CrossRef] [PubMed]

132. Chittoor-Vinod, V.G.; Villalobos-Cantor, S.; Roshak, H.; Shea, K.; Abalde-Atristain, L.; Martin, I. Dietary Amino Acids Impact LRRK2-Induced Neurodegeneration in Parkinson's Disease Models. J. Neurosci. Off. J. Soc. Neurosci. 2020, 40, 6234-6249. [CrossRef] [PubMed]

133. Yahalom, G.; Rigbi, A.; Israeli-Korn, S.; Krohn, L.; Rudakou, U.; Ruskey, J.A.; Benshimol, L.; Tsafnat, T.; Gan-Or, Z.; Hassin-Baer, S.; et al. Age at Onset of Parkinson's Disease Among Ashkenazi Jewish Patients: Contribution of Environmental Factors, LRRK2 p.G2019S and GBA p.N370S Mutations. J. Parkinsons Dis. 2020. [CrossRef] [PubMed]

134. San Luciano, M.; Tanner, C.M.; Meng, C.; Marras, C.; Goldman, S.M.; Lang, A.E.; Tolosa, E.; Schüle, B.; Langston, J.W.; Brice, A.; et al. Nonsteroidal Anti-Inflammatory Use and LRRK2 Parkinson's Disease Penetrance. Mov. Disord. 2020. [CrossRef] [PubMed]

135. Kuwahara, T.; Funakawa, K.; Komori, T.; Sakurai, M.; Yoshii, G.; Eguchi, T.; Fukuda, M.; Iwatsubo, T. Roles of lysosomotropic agents on LRRK2 activation and Rab10 phosphorylation. Neurobiol. Dis. 2020, 145, 105081. [CrossRef]

136. Herbst, S.; Campbell, P.; Harvey, J.; Bernard, E.M.; Papayannopoulos, V.; Wood, N.W.; Morris, H.R.; Gutierrez, M.G. LRRK2 activation controls the repair of damaged endomembranes in macrophages. EMBO J. 2020, 39, e104494. [CrossRef] 
137. Hsieh, C.H.; Shaltouki, A.; Gonzalez, A.E.; Bettencourt da Cruz, A.; Burbulla, L.F.; St Lawrence, E.; Schüle, B.; Krainc, D.; Palmer, T.D.; Wang, X. Functional Impairment in Miro Degradation and Mitophagy Is a Shared Feature in Familial and Sporadic Parkinson's Disease. Cell Stem. Cell 2016, 19, 709-724. [CrossRef]

138. Cabezudo, D.; Baekelandt, V.; Lobbestael, E. Multiple-Hit Hypothesis in Parkinson's Disease: LRRK2 and Inflammation. Front. Neurosci. 2020, 14, 376. [CrossRef]

139. Patrick, K.L.; Bell, S.L.; Weindel, C.G.; Watson, R.O. Exploring the "Multiple-Hit Hypothesis" of Neurodegenerative Disease: Bacterial Infection Comes Up to Bat. Front. Cell Infect. Microbiol. 2019, 9, 138. [CrossRef]

140. Perez-Rodriguez, D.; Kalyva, M.; Leija-Salazar, M.; Lashley, T.; Tarabichi, M.; Chelban, V.; Gentleman, S.; Schottlaender, L.; Franklin, H.; Vasmatzis, G.; et al. Investigation of somatic CNVs in brains of synucleinopathy cases using targeted SNCA analysis and single cell sequencing. Acta Neuropathol. Commun. 2019, 7, 219. [CrossRef]

141. Albanese, F.; Novello, S.; Morari, M. Autophagy and LRRK2 in the Aging Brain. Front. Neurosci. 2019, 13, 1352. [CrossRef] [PubMed]

142. Langston, J.W.; Ballard, P. Parkinsonism induced by 1-methyl-4-phenyl-1,2,3,6-tetrahydropyridine (MPTP): Implications for treatment and the pathogenesis of Parkinson's disease. Can. J. Neurol. Sci. 1984, 11, 160-165. [CrossRef] [PubMed]

143. Langston, J.W.; Forno, L.S.; Tetrud, J.; Reeves, A.G.; Kaplan, J.A.; Karluk, D. Evidence of active nerve cell degeneration in the substantia nigra of humans years after 1-methyl-4-phenyl-1,2,3,6-tetrahydropyridine exposure. Ann. Neurol. 1999, 46, 598-605. [CrossRef]

144. Karuppagounder, S.S.; Xiong, Y.; Lee, Y.; Lawless, M.C.; Kim, D.; Nordquist, E.; Martin, I.; Ge, P.; Brahmachari, S.; Jhaldiyal, A.; et al. LRRK2 G2019S transgenic mice display increased susceptibility to 1-methyl-4-phenyl-1,2,3,6-tetrahydropyridine (MPTP)-mediated neurotoxicity. J. Chem. Neuroanat. 2016, 76, 90-97. [CrossRef] [PubMed]

145. Arbez, N.; He, X.; Huang, Y.; Ren, M.; Liang, Y.; Nucifora, F.C.; Wang, X.; Pei, Z.; Tessarolo, L.; Smith, W.W.; et al. G2019S-LRRK2 mutation enhances MPTP-linked Parkinsonism in mice. Hum. Mol. Genet. 2020, 29, 580-590. [CrossRef] [PubMed]

146. Andres-Mateos, E.; Mejias, R.; Sasaki, M.; Li, X.; Lin, B.M.; Biskup, S.; Zhang, L.; Banerjee, R.; Thomas, B.; Yang, L.; et al. Unexpected lack of hypersensitivity in LRRK2 knock-out mice to MPTP (1-methyl-4-phenyl-1,2,3,6-tetrahydropyridine). J. Neurosci. Off. J. Soc. Neurosci. 2009, 29, 15846-15850. [CrossRef]

147. Wang, S.; Zhang, X.; Guo, Y.; Rong, H.; Liu, T. The long noncoding RNA HOTAIR promotes Parkinson's disease by upregulating LRRK2 expression. Oncotarget 2017, 8, 24449-24456. [CrossRef]

148. Shi, L.; Huang, C.; Luo, Q.; Xia, Y.; Liu, H.; Li, L.; Liu, W.; Ma, W.; Fang, J.; Tang, L.; et al. Pilot study: Molecular risk factors for diagnosing sporadic Parkinson's disease based on gene expression in blood in MPTP-induced rhesus monkeys. Oncotarget 2017, 8, 105606-105614. [CrossRef]

149. Rudyk, C.; Dwyer, Z.; Hayley, S.; Membership, C. Leucine-rich repeat kinase-2 (LRRK2) modulates paraquat-induced inflammatory sickness and stress phenotype. J. Neuroinflammation 2019, 16, 120. [CrossRef]

150. Shaikh, K.T.; Yang, A.; Youshin, E.; Schmid, S. Transgenic LRRK2 (R1441G) rats-a model for Parkinson disease? PeerJ 2015, 3, e945. [CrossRef]

151. Quintero-Espinosa, D.; Jimenez-Del-Rio, M.; Velez-Pardo, C. Knockdown transgenic Lrrk Drosophila resists paraquat-induced locomotor impairment and neurodegeneration: A therapeutic strategy for Parkinson's disease. Brain Res. 2017, 1657, $253-261$. [CrossRef] [PubMed]

152. Imai, Y.; Gehrke, S.; Wang, H.Q.; Takahashi, R.; Hasegawa, K.; Oota, E.; Lu, B. Phosphorylation of 4E-BP by LRRK2 affects the maintenance of dopaminergic neurons in Drosophila. EMBO J. 2008, 27, 2432-2443. [CrossRef] [PubMed]

153. Cannon, J.R.; Tapias, V.; Na, H.M.; Honick, A.S.; Drolet, R.E.; Greenamyre, J.T. A highly reproducible rotenone model of Parkinson's disease. Neurobiol. Dis. 2009, 34, 279-290. [CrossRef] [PubMed]

154. Sherer, T.B.; Betarbet, R.; Testa, C.M.; Seo, B.B.; Richardson, J.R.; Kim, J.H.; Miller, G.W.; Yagi, T.; Matsuno-Yagi, A.; Greenamyre, J.T. Mechanism of toxicity in rotenone models of Parkinson's disease. J. Neurosci. Off. J. Soc. Neurosci. 2003, 23, 10756-10764. [CrossRef]

155. Liu, H.F.; Ho, P.W.; Leung, G.C.; Lam, C.S.; Pang, S.Y.; Li, L.; Kung, M.H.; Ramsden, D.B.; Ho, S.L. Combined LRRK2 mutation, aging and chronic low dose oral rotenone as a model of Parkinson's disease. Sci. Rep. 2017, 7, 40887. [CrossRef] [PubMed]

156. Venderova, K.; Kabbach, G.; Abdel-Messih, E.; Zhang, Y.; Parks, R.J.; Imai, Y.; Gehrke, S.; Ngsee, J.; Lavoie, M.J.; Slack, R.S.; et al. Leucine-Rich Repeat Kinase 2 interacts with Parkin, DJ-1 and PINK-1 in a Drosophila melanogaster model of Parkinson's disease. Hum. Mol. Genet. 2009, 18, 4390-4404. [CrossRef]

157. Ng, C.H.; Mok, S.Z.; Koh, C.; Ouyang, X.; Fivaz, M.L.; Tan, E.K.; Dawson, V.L.; Dawson, T.M.; Yu, F.; Lim, K.L. Parkin protects against LRRK2 G2019S mutant-induced dopaminergic neurodegeneration in Drosophila. J. Neurosci. Off. J. Soc. Neurosci. 2009, 29, 11257-11262. [CrossRef]

158. Rocha, E.M.; De Miranda, B.R.; Castro, S.; Drolet, R.; Hatcher, N.G.; Yao, L.; Smith, S.M.; Keeney, M.T.; Di Maio, R.; Kofler, J.; et al. LRRK2 inhibition prevents endolysosomal deficits seen in human Parkinson's disease. Neurobiol. Dis. 2020, 134, 104626. [CrossRef]

159. Mendivil-Perez, M.; Velez-Pardo, C.; Jimenez-Del-Rio, M. Neuroprotective Effect of the LRRK2 Kinase Inhibitor PF-06447475 in Human Nerve-Like Differentiated Cells Exposed to Oxidative Stress Stimuli: Implications for Parkinson's Disease. Neurochem Res. 2016, 41, 2675-2692. [CrossRef] 
160. Reinhardt, P.; Schmid, B.; Burbulla, L.F.; Schondorf, D.C.; Wagner, L.; Glatza, M.; Hoing, S.; Hargus, G.; Heck, S.A.; Dhingra, A.; et al. Genetic correction of a LRRK2 mutation in human iPSCs links parkinsonian neurodegeneration to ERK-dependent changes in gene expression. Cell Stem. Cell 2013, 12, 354-367. [CrossRef]

161. Cannon, J.R.; Greenamyre, J.T. Gene-environment interactions in Parkinson's disease: Specific evidence in humans and mammalian models. Neurobiol. Dis. 2013, 57, 38-46. [CrossRef] [PubMed]

162. Manning-Bog, A.B.; Langston, J.W. Model fusion, the next phase in developing animal models for Parkinson's disease. Neurotox Res. 2007, 11, 219-240. [CrossRef] [PubMed]

163. Varçin, M.; Bentea, E.; Michotte, Y.; Sarre, S. Oxidative Stress in Genetic Mouse Models of Parkinson's Disease. Oxidative Med. Cell. Longev. 2012, 2012, 624925. [CrossRef] [PubMed]

164. Yu, W.H.; Matsuoka, Y.; Sziráki, I.; Hashim, A.; Lafrancois, J.; Sershen, H.; Duff, K.E. Increased dopaminergic neuron sensitivity to 1-methyl-4-phenyl-1,2,3,6-tetrahydropyridine (MPTP) in transgenic mice expressing mutant A53T alpha-synuclein. Neurochem. Res. 2008, 33, 902-911. [CrossRef]

165. Lee, S.; Oh, S.T.; Jeong, H.J.; Pak, S.C.; Park, H.J.; Kim, J.; Cho, H.S.; Jeon, S. MPTP-induced vulnerability of dopamine neurons in A53T alpha-synuclein overexpressed mice with the potential involvement of DJ-1 downregulation. Korean J. Physiol. Pharmacol. 2017, 21, 625-632. [CrossRef] [PubMed]

166. Yasuda, T.; Hayakawa, H.; Nihira, T.; Ren, Y.R.; Nakata, Y.; Nagai, M.; Hattori, N.; Miyake, K.; Takada, M.; Shimada, T.; et al. Parkin-mediated protection of dopaminergic neurons in a chronic MPTP-minipump mouse model of Parkinson disease. $J$. Neuropathol. Exp. Neurol. 2011, 70, 686-697. [CrossRef]

167. Bieri, G.; Brahic, M.; Bousset, L.; Couthouis, J.; Kramer, N.J.; Ma, R.; Nakayama, L.; Monbureau, M.; Defensor, E.; Schüle, B.; et al. LRRK2 modifies alpha-syn pathology and spread in mouse models and human neurons. Acta Neuropathol. 2019, 137, 961-980. [CrossRef]

168. Purlyte, E.; Dhekne, H.S.; Sarhan, A.R.; Gomez, R.; Lis, P.; Wightman, M.; Martinez, T.N.; Tonelli, F.; Pfeffer, S.R.; Alessi, D.R. Rab29 activation of the Parkinson's disease-associated LRRK2 kinase. EMBO J. 2018, 37, 1-18. [CrossRef]

169. Botta-Orfila, T.; Ezquerra, M.; Pastor, P.; Fernandez-Santiago, R.; Pont-Sunyer, C.; Compta, Y.; Lorenzo-Betancor, O.; Samaranch, L.; Marti, M.J.; Valldeoriola, F.; et al. Age at onset in LRRK2-associated PD is modified by SNCA variants. J. Mol. Neurosci. 2012, 48, 245-247. [CrossRef]

170. Gan-Or, Z.; Bar-Shira, A.; Mirelman, A.; Gurevich, T.; Giladi, N.; Orr-Urtreger, A. The age at motor symptoms onset in LRRK2associated Parkinson's disease is affected by a variation in the MAPT locus: A possible interaction. J. Mol. Neurosci. 2012, 46, 541-544. [CrossRef]

171. Trinh, J.; Gustavsson, E.K.; Guella, I.; Vilarino-Guell, C.; Evans, D.; Encarnacion, M.; Sherman, H.; Hentati, F.; Farrer, M.J. The role of SNCA and MAPT in Parkinson disease and LRRK2 parkinsonism in the Tunisian Arab-Berber population. Eur. J. Neurol. 2014, 21, e91-e92. [CrossRef] [PubMed]

172. Trinh, J.; Gustavsson, E.K.; Vilarino-Guell, C.; Bortnick, S.; Latourelle, J.; McKenzie, M.B.; Tu, C.S.; Nosova, E.; Khinda, J.; Milnerwood, A.; et al. DNM3 and genetic modifiers of age of onset in LRRK2 Gly2019Ser parkinsonism: A genome-wide linkage and association study. Lancet Neurol. 2016, 15, 1248-1256. [CrossRef]

173. Fernandez-Santiago, R.; Garrido, A.; Infante, J.; Gonzalez-Aramburu, I.; Sierra, M.; Fernandez, M.; Valldeoriola, F.; Munoz, E.; Compta, Y.; Marti, M.J.; et al. Alpha-synuclein (SNCA) but not dynamin 3 (DNM3) influences age at onset of leucine-rich repeat kinase 2 (LRRK2) Parkinson's disease in Spain. Mov. Disord. 2018, 33, 637-641. [CrossRef]

174. Brown, E.E.; Blauwendraat, C.; Trinh, J.; Rizig, M.; Nalls, M.A.; Leveille, E.; Ruskey, J.A.; Jonvik, H.; Tan, M.M.X.; BandresCiga, S.; et al. Analysis of DNM3 and VAMP4 as genetic modifiers of LRRK2 Parkinson's disease. Neurobiol. Aging 2021, 97, 148.e117-148.e124. [CrossRef] [PubMed]

175. Liu, J.; Zhou, Y.; Wang, C.; Wang, T.; Zheng, Z.; Chan, P. Brain-derived neurotrophic factor (BDNF) genetic polymorphism greatly increases risk of leucine-rich repeat kinase 2 (LRRK2) for Parkinson's disease. Parkinsonism Relat. Disord. 2012, 18, 140-143. [CrossRef] [PubMed]

176. Dan, X.; Wang, C.; Ma, J.; Feng, X.; Wang, T.; Zheng, Z.; Chan, P. MAPT IVS1+124 C>G modifies risk of LRRK2 G2385R for Parkinson's disease in Chinese individuals. Neurobiol. Aging 2014, 35, 1780.e7-1780.e10. [CrossRef] [PubMed]

177. Wang, C.; Cai, Y.; Zheng, Z.; Tang, B.S.; Xu, Y.; Wang, T.; Ma, J.; Chen, S.D.; Langston, J.W.; Tanner, C.M.; et al. Penetrance of LRRK2 G2385R and R1628P is modified by common PD-associated genetic variants. Parkinsonism Relat. Disord. 2012, 18, 958-963. [CrossRef] [PubMed]

178. Yang, Z.H.; Li, Y.S.; Shi, M.M.; Yang, J.; Liu, Y.T.; Mao, C.Y.; Fan, Y.; Hu, X.C.; Shi, C.H.; Xu, Y.M. SNCA but not DNM3 and GAK modifies age at onset of LRRK2-related Parkinson's disease in Chinese population. J. Neurol. 2019, 266, 1796-1800. [CrossRef] [PubMed]

179. Soto-Ortolaza, A.I.; Heckman, M.G.; Labbe, C.; Serie, D.J.; Puschmann, A.; Rayaprolu, S.; Strongosky, A.; Boczarska-Jedynak, M.; Opala, G.; Krygowska-Wajs, A.; et al. GWAS risk factors in Parkinson's disease: LRRK2 coding variation and genetic interaction with PARK16. Am. J. Neurodegener Dis. 2013, 2, 287-299.

180. Wang, L.; Heckman, M.G.; Aasly, J.O.; Annesi, G.; Bozi, M.; Chung, S.J.; Clarke, C.; Crosiers, D.; Eckstein, G.; Garraux, G.; et al. Evaluation of the interaction between LRRK2 and PARK16 loci in determining risk of Parkinson's disease: Analysis of a large multicenter study. Neurobiol. Aging 2017, 49, 217.e211-217.e214. [CrossRef] 
181. Golub, Y.; Berg, D.; Calne, D.B.; Pfeiffer, R.F.; Uitti, R.J.; Stoessl, A.J.; Wszolek, Z.K.; Farrer, M.J.; Mueller, J.C.; Gasser, T.; et al. Genetic factors influencing age at onset in LRRK2-linked Parkinson disease. Parkinsonism Relat. Disord. 2009, 15, 539-541. [CrossRef] [PubMed]

182. Nalls, M.A.; Pankratz, N.; Lill, C.M.; Do, C.B.; Hernandez, D.G.; Saad, M.; DeStefano, A.L.; Kara, E.; Bras, J.; Sharma, M.; et al. Large-scale meta-analysis of genome-wide association data identifies six new risk loci for Parkinson's disease. Nat. Genet. 2014, 46, 989-993. [CrossRef] [PubMed]

183. Chang, D.; Nalls, M.A.; Hallgrimsdottir, I.B.; Hunkapiller, J.; van der Brug, M.; Cai, F.; International Parkinson's Disease Genomics Consortium; 23andMe Research Team; Kerchner, G.A.; Ayalon, G.; et al. A meta-analysis of genome-wide association studies identifies 17 new Parkinson's disease risk loci. Nat. Genet. 2017, 49, 1511-1516. [CrossRef] [PubMed]

184. Nalls, M.A.; Blauwendraat, C.; Vallerga, C.L.; Heilbron, K.; Bandres-Ciga, S.; Chang, D.; Tan, M.; Kia, D.A.; Noyce, A.J.; Xue, A.; et al. Expanding Parkinson's disease genetics: Novel risk loci, genomic context, causal insights and heritable risk. bioRxiv 2019, 388165. [CrossRef]

185. Germer, E.L.; Imhoff, S.; Vilariño-Güell, C.; Kasten, M.; Seibler, P.; Brüggemann, N.; Klein, C.; Trinh, J. The Role of Rare Coding Variants in Parkinson's Disease GWAS Loci. Front. Neurol. 2019, 10, 1284. [CrossRef]

186. International Parkinson's Disease Genomics Consortium; Nalls, M.A.; Plagnol, V.; Hernandez, D.G.; Sharma, M.; Sheerin, U.M.; Saad, M.; Simon-Sanchez, J.; Schulte, C.; Lesage, S.; et al. Imputation of sequence variants for identification of genetic risks for Parkinson's disease: A meta-analysis of genome-wide association studies. Lancet 2011, 377, 641-649. [CrossRef]

187. Lill, C.M.; Roehr, J.T.; McQueen, M.B.; Kavvoura, F.K.; Bagade, S.; Schjeide, B.M.; Schjeide, L.M.; Meissner, E.; Zauft, U.; Allen, N.C.; et al. Comprehensive research synopsis and systematic meta-analyses in Parkinson's disease genetics: The PDGene database. PLoS Genet. 2012, 8, e1002548. [CrossRef]

188. Lai, D.; Alipanahi, B.; Fontanillas, P.; Schwantes-An, T.-H.; Aasly, J.; Alcalay, R.N.; Beecham, G.W.; Berg, D.; Bressman, S.; Brice, A.; et al. Genome-wide association studies of LRRK2 modifiers of Parkinson's disease. medRxiv 2020. [CrossRef]

189. Iwaki, H.; Blauwendraat, C.; Makarious, M.B.; Bandres-Ciga, S.; Leonard, H.L.; Gibbs, J.R.; Hernandez, D.G.; Scholz, S.W.; Faghri, F.; International Parkinson's Disease Genomics Consortium; et al. Penetrance of Parkinson's Disease in LRRK2 p.G2019S Carriers Is Modified by a Polygenic Risk Score. Mov. Disord. 2020. [CrossRef]

190. Yahalom, G.; Greenbaum, L.; Israeli-Korn, S.; Fay-Karmon, T.; Livneh, V.; Ruskey, J.A.; Roncière, L.; Alam, A.; Gan-Or, Z.; Hassin-Baer, S. Carriers of both GBA and LRRK2 mutations, compared to carriers of either, in Parkinson's disease: Risk estimates and genotype-phenotype correlations. Parkinsonism Relat. Disord. 2019, 62, 179-184. [CrossRef]

191. Omer, N.; Giladi, N.; Gurevich, T.; Bar-Shira, A.; Gana-Weisz, M.; Goldstein, O.; Kestenbaum, M.; Cedarbaum, J.M.; Orr-Urtreger, A.; Mirelman, A.; et al. A Possible Modifying Effect of the G2019S Mutation in the LRRK2 Gene on GBA Parkinson's Disease. Mov. Disord. 2020, 35, 1249-1253. [CrossRef] [PubMed]

192. Ross, O.A.; Soto-Ortolaza, A.I.; Heckman, M.G.; Aasly, J.O.; Abahuni, N.; Annesi, G.; Bacon, J.A.; Bardien, S.; Bozi, M.; Brice, A.; et al. Association of LRRK2 exonic variants with susceptibility to Parkinson's disease: A case-control study. Lancet Neurol. 2011, 10, 898-908. [CrossRef]

193. Tan, E.K.; Peng, R.; Teo, Y.Y.; Tan, L.C.; Angeles, D.; Ho, P.; Chen, M.L.; Lin, C.H.; Mao, X.Y.; Chang, X.L.; et al. Multiple LRRK2 variants modulate risk of Parkinson disease: A Chinese multicenter study. Hum. Mutat 2010, 31, 561-568. [CrossRef] [PubMed]

194. Wu, Y.R.; Chang, K.H.; Chang, W.T.; Hsiao, Y.C.; Hsu, H.C.; Jiang, P.R.; Chen, Y.C.; Chao, C.Y.; Chang, Y.C.; Lee, B.H.; et al. Genetic variants ofLRRK2 in Taiwanese Parkinson's disease. PLoS ONE 2013, 8, e82001. [CrossRef]

195. Gopalai, A.A.; Lim, J.L.; Li, H.H.; Zhao, Y.; Lim, T.T.; Eow, G.B.; Puvanarajah, S.; Viswanathan, S.; Norlinah, M.I.; Abdul Aziz, Z.; et al. LRRK2 N551K and R1398H variants are protective in Malays and Chinese in Malaysia: A case-control association study for Parkinson's disease. Mol. Genet. Genomic Med. 2019, 7, e604. [CrossRef]

196. Chen, L.; Zhang, S.; Liu, Y.; Hong, H.; Wang, H.; Zheng, Y.; Zhou, H.; Chen, J.; Xian, W.; He, Y.; et al. LRRK2 R1398H polymorphism is associated with decreased risk of Parkinson's disease in a Han Chinese population. Parkinsonism Relat. Disord. 2011, 17, 291-292. [CrossRef]

197. Heckman, M.G.; Schottlaender, L.; Soto-Ortolaza, A.I.; Diehl, N.N.; Rayaprolu, S.; Ogaki, K.; Fujioka, S.; Murray, M.E.; Cheshire, W.P.; Uitti, R.J.; et al. LRRK2 exonic variants and risk of multiple system atrophy. Neurology 2014, 83, 2256-2261. [CrossRef]

198. Ng, A.S.L.; Ng, E.Y.L.; Tan, Y.J.; Prakash, K.M.; Au, W.L.; Tan, L.C.S.; Tan, E.K. Case-control analysis of LRRK2 protective variants in Essential Tremor. Sci. Rep. 2018, 8, 5346. [CrossRef]

199. Ng, A.S.L.; Ng, E.Y.L.; Tan, Y.J.; Kandiah, N.; Zhou, J.; Hameed, S.; Ting, S.K.S.; Tan, E.K. Case-control analysis of leucine-rich repeat kinase 2 protective variants in Alzheimer's disease. Neurobiol. Aging 2018, 64, e157-e159. [CrossRef]

200. Ma, D.; Tio, M.; Ng, S.H.; Li, Z.; Lim, C.Y.; Zhao, Y.; Tan, E.K. Derivation of human induced pluripotent stem cell (iPSC) line with LRRK2 gene R1398H variant in Parkinson's disease. Stem. Cell Res. 2017, 18, 48-50. [CrossRef]

201. Ma, D.; Ng, E.Y.; Zeng, L.; Lim, C.Y.; Zhao, Y.; Tan, E.K. Development of a human induced pluripotent stem cell (iPSC) line from a Parkinson's disease patient carrying the N551K variant in LRRK2 gene. Stem. Cell Res. 2017, 18, 51-53. [CrossRef]

202. Madzar, D.; Schulte, C.; Gasser, T. Screening for LRRK2 R1441 mutations in a cohort of PSP patients from Germany. Eur. J. Neurol. 2009, 16, 1230-1232. [CrossRef] [PubMed]

203. Ross, O.A.; Whittle, A.J.; Cobb, S.A.; Hulihan, M.M.; Lincoln, S.J.; Toft, M.; Farrer, M.J.; Dickson, D.W. Lrrk2 R1441 substitution and progressive supranuclear palsy. Neuropathol. Appl. Neurobiol. 2006, 32, 23-25. [CrossRef] [PubMed]

204. Chen-Plotkin, A.S. LRRK2 and survival in progressive supranuclear palsy. Lancet Neurol. 2020. [CrossRef] 
205. Jabbari, E.; Koga, S.; Valentino, R.R.; Reynolds, R.H.; Ferrari, R.; Tan, M.M.X.; Rowe, J.B.; Dalgard, C.L.; Scholz, S.W.; Dickson, D.W.; et al. Genetic determinants of survival in progressive supranuclear palsy: A genome-wide association study. Lancet Neurol. 2020. [CrossRef]

206. Heckman, M.G.; Soto-Ortolaza, A.I.; Contreras, M.Y.S.; Murray, M.E.; Pedraza, O.; Diehl, N.N.; Walton, R.; Labbe, C.; LorenzoBetancor, O.; Uitti, R.J.; et al. LRRK2 variation and dementia with Lewy bodies. Parkinsonism Relat. Disord. 2016, $31,98-103$. [CrossRef] [PubMed]

207. Yuan, X.; Chen, Y.; Cao, B.; Zhao, B.; Wei, Q.; Guo, X.; Yang, Y.; Yuan, L.; Shang, H. An association analysis of the R1628P and G2385R polymorphisms of the LRRK2 gene in multiple system atrophy in a Chinese population. Parkinsonism Relat. Disord. 2015, 21, 147-149. [CrossRef] [PubMed]

208. Ozelius, L.J.; Foroud, T.; May, S.; Senthil, G.; Sandroni, P.; Low, P.A.; Reich, S.; Colcher, A.; Stern, M.B.; Ondo, W.G.; et al. G2019S mutation in the leucine-rich repeat kinase 2 gene is not associated with multiple system atrophy. Mov. Disord. 2007, 22, 546-549. [CrossRef]

209. Cho, J.W.; Kim, S.Y.; Park, S.S.; Jeon, B.S. The G2019S LRRK2 Mutation is Rare in Korean Patients with Parkinson's Disease and Multiple System Atrophy. J. Clin. Neurol. 2009, 5, 29-32. [CrossRef]

210. Fatahian, R.; Bagheri, S.R.; Sadeghi, M. A meta-analysis of leucine-rich repeat kinase 2 (LRRK2) polymorphisms in Alzheimer's disease. Folia Neuropathol. 2019, 57, 1-5. [CrossRef]

211. Deng, H.; Le, W.; Davidson, A.L.; Xie, W.; Jankovic, J. The LRRK2 I2012T, G2019S and I2020T mutations are not common in patients with essential tremor. Neurosci. Lett. 2006, 407, 97-100. [CrossRef] [PubMed]

212. Tan, E.K.; Lee, J.; Lim, H.Q.; Yuen, Y.; Zhao, Y. Essential tremor and the common LRRK2 G2385R variant. Parkinsonism Relat. Disord. 2008, 14, 569-571. [CrossRef] [PubMed]

213. Vitale, C.; Ciotti, P.; Gulli, R.; Bellone, E.; Scaglione, C.; Abbruzzese, G.; Martinelli, P.; Barone, P.; Mandich, P. Common mutations in the LRRK2 exon 41 are not responsible for essential tremor in Italian patients. Parkinsonism Relat. Disord. 2009, 15, 162-163. [CrossRef] [PubMed]

214. Clark, L.N.; Kisselev, S.; Park, N.; Ross, B.; Verbitsky, M.; Rios, E.; Alcalay, R.N.; Lee, J.H.; Louis, E.D. Mutations in the Parkinson's disease genes, Leucine Rich Repeat Kinase 2 (LRRK2) and Glucocerebrosidase (GBA), are not associated with essential tremor. Parkinsonism Relat. Disord. 2010, 16, 132-135. [CrossRef]

215. Chen, H.; Yuan, L.; Song, Z.; Deng, X.; Yang, Z.; Gong, L.; Zi, X.; Deng, H. Genetic Analysis of LRRK1 and LRRK2 Variants in Essential Tremor Patients. Genet. Test. Mol. Biomarkers 2018, 22, 398-402. [CrossRef]

216. Chao, Y.X.; Ng, E.Y.; Tan, L.; Prakash, K.M.; Au, W.L.; Zhao, Y.; Tan, E.K. Lrrk2 R1628P variant is a risk factor for essential tremor. Sci. Rep. 2015, 5, 9029. [CrossRef]

217. Brudek, T. Inflammatory Bowel Diseases and Parkinson's Disease. J. Parkinsons Dis. 2019, 9, S331-S344. [CrossRef]

218. Zhu, F.; Li, C.; Gong, J.; Zhu, W.; Gu, L.; Li, N. The risk of Parkinson's disease in inflammatory bowel disease: A systematic review and meta-analysis. Dig. Liver Dis. 2019, 51, 38-42. [CrossRef]

219. Fuji, R.N.; Flagella, M.; Baca, M.; MA, S.B.; Brodbeck, J.; Chan, B.K.; Fiske, B.K.; Honigberg, L.; Jubb, A.M.; Katavolos, P.; et al. Effect of selective LRRK2 kinase inhibition on nonhuman primate lung. Sci. Transl. Med. 2015, 7, 273ra15. [CrossRef]

220. Baptista, M.A.S.; Merchant, K.; Barrett, T.; Bhargava, S.; Bryce, D.K.; Ellis, J.M.; Estrada, A.A.; Fell, M.J.; Fiske, B.K.; Fuji, R.N.; et al. LRRK2 inhibitors induce reversible changes in nonhuman primate lungs without measurable pulmonary deficits. Sci. Transl. Med. 2020, 12, eaav0820. [CrossRef]

221. Ahadi, S.; Zhou, W.; Schussler-Fiorenza Rose, S.M.; Sailani, M.R.; Contrepois, K.; Avina, M.; Ashland, M.; Brunet, A.; Snyder, M. Personal aging markers and ageotypes revealed by deep longitudinal profiling. Nat. Med. 2020, 26, 83-90. [CrossRef] [PubMed] 